\title{
Environmental Survey of the B-3 and Ford's Farm Ranges
}

\author{
G. A. Stoetzel \\ D. A. Waite \\ R. L. Gilchrist, Project Manager
}

August 1983

Prepared for

the U.S. Department of the Army

under a Related Services Agreement

with the U.S. Department of Energy

under Contract DE-AC06-76RLO 1830

Pacific Northwest Laboratory

Operated for the U.S. Department of Energy

by Battelle Memorial Institute 


\title{
DISCLAIMER
}

This report was prepared as an account of work sponsored by an agency of the United States Government. Neither the United States Government nor any agency thereof, nor any of their employees, makes any warranty, express or implied, or assumes any legal liability or responsibility for the accuracy, completeness, or usefulness of any information, apparatus, product, or process disclosed, or represents that its use would not infringe privately owned rights. Reference herein to any specific commercial product, process, or service by trade name, trademark, manufacturer, or otherwise, does not necessarily constitute or imply its endorsement, recommendation, or favoring by the United States Government or any agency thereof. The views and opinions of authors expressed herein do not necessarily state or reflect those of the United States Government or any agency thereof.

\author{
PACIFIC NORTHWEST LABORATORY \\ operated by \\ BATTELLE \\ for the \\ UNITED STATES DEPARTMENT OF ENERGY \\ under Contract DE-AC06-76RLO 1830
}

\begin{tabular}{|c|c|}
\hline \multicolumn{2}{|c|}{$\begin{array}{l}\text { Printed in the United States of America } \\
\text { Available from } \\
\text { National Technical Information Service } \\
\text { United States Department of Commerce } \\
5285 \text { Port Royal Road } \\
\text { Springfield, Virginia } 22161\end{array}$} \\
\hline \multicolumn{2}{|c|}{$\begin{array}{l}\text { NTIS Price Codes } \\
\text { Microfiche A01 }\end{array}$} \\
\hline \multicolumn{2}{|c|}{ Printed Copy } \\
\hline Pages & $\begin{array}{l}\text { Price } \\
\text { Codes }\end{array}$ \\
\hline $001-025$ & $\mathrm{~A} 02$ \\
\hline $026-050$ & $\mathrm{~A} 03$ \\
\hline $051-075$ & $\mathrm{~A} 04$ \\
\hline $076-100$ & A05 \\
\hline $101-125$ & A 06 \\
\hline $126-150$ & $A 07$ \\
\hline $151-175$ & $\mathrm{~A} 08$ \\
\hline $176-200$ & $A 09$ \\
\hline $201-225$ & A010 \\
\hline $226-250$ & A011 \\
\hline $251-275$ & $\mathrm{~A} 012$ \\
\hline $276-300$ & $\mathrm{~A} 013$ \\
\hline
\end{tabular}


PNL-2976

UC -35

\title{
33679000536203
}

\section{ENVIRONMENTAL SURVEY \\ OF THE B-3 AND \\ FORD'S FARM RANGES}
G. A. Stoetzel
D. A. Waite(a)
R. L. Gilchrist, Project Manager

Report Completed May 1979

Published August 1983

\begin{abstract}
Prepared for
the U.S. Department of the Army under a Related Services Agreement with the U.S. Department of Energy under Contract DE-AC06-76RLO 1830
\end{abstract}

Pacific Northwest Laboratory Richland, Washington 99352

(a) Office of Nuclear Waste Isolation Columbus, Ohio 


\section{PREFACE}

This study was conducted on the recommendation of the Joint Technical Coordinating Group for Munitions Effectiveness (JTCG/ME), Working Group on Depleted Uranium, and was supported by the Office of Assistant Project Manager for Tank Main Armament Development, XM1 Tank System, under Army Project Number IL6636080060. The technical monitors were the Working Group Chairman, Ernest W. Bloore, and Edward F. Wilsey, both of the U.S. Army Armament Research and Development Command, Dover, New Jersey.

The authors wish to acknowledge the support of personnel of the Material Testing Directorate of the Testing and Evaluation Command, especially Mr. K. Ruff, in conducting the part of the study at Aberdeen Proving Ground, MI. A debt of gratitude is also owed to J. M. Aldrich and C. D. Hooker of Pacific Northwest Laboratory, who assisted in data collection during the two site visits to the Proving Ground, and to J. L. Baer, who edited the report. 
SUMMARY

As part of its armaments testing program, the Army has been firing depleted-uranium (DU) projectiles into targets on the Aberdeen Proving Ground, Maryland. The purpose of the study reported on here was to conduct an environmental survey of two areas known as the B-3 range and the Ford's Farm range to determine the location of DU in their environments. The survey, conducted by the Pacific Northwest Laboratory, included ground survey measurements and some environmental sampling. Several special studies were also conducted, including analyses of the isotopic composition of uranium in a limited number of samples and a dissolution rate study to estimate the solubility of DU dust in sea and river water.

Analysis of the ground survey measurements showed count rates of radioactivity at about twice background levels within about a $100-m$ radius of the Ford's Farm target and DU fragments in scattered locations as far as $190 \mathrm{~m}$ from the target. The count rates from the ground survey of the B-3 range and areas surrounding the Ford's Farm range were at about background levels.

The average uranium concentrations in soil samples were $1.3 \mu \mathrm{g} / \mathrm{g}$ of soil froin the B-3 range and $3.6 \mu \mathrm{g} / \mathrm{g}$ of soil from Ford's Farm. From analyses of these results, it was concluded that:

- samples collected from each area represent statistically different average uranium concentrations

- the degree of sampling variability is about the same for each area

- the uranium content of the B-3 range's soil is similar to that of a reference area (an area on the Proving Ground chosen to represent an unaffected area) and the uranium content of the Ford's Farm soil is higher than that of the reference area

- uranium concentrations in soil samples collected from areas around Ford's Farm are lower than those in reference area samples.

A limited number of soil profile analyses indicated that uranium concentrations generally decrease with depth. 
The uranium concentrations found in stream sediment, water, and vegetation samples collected from the B-3 range and the Ford's Farm range were variable, with the highest concentrations found in samples collected near the Ford's Farm target. Uranium concentrations in the reference area samples were similar to the lower values for sediment, water, and vegetation samples collected from the B-3 range and the Ford's Farm range.

It was concluded from the results of the special studies that:

- the isotopic compositions of environmental samples from the reference area, Ford's Farm, and some surrounding areas approximate the calculated isotopic composition of DU

- DU dust is relatively insoluble in sea water and river water. An evaluation of the results of this environmental survey indicates that several additional studies are needed to detail the extent of DU movement from the target areas. Suggested studies include:

- determination of the background level of uranium for the region

- further characterization of the soil in the area around the Ford's Farm target.

- air sampling at several locations at and near Ford's Farm

- characterization of stream sediments and shellfish at the estuaries of appropriate creeks draining the Proving Ground.

A routine environmental-surveillance program should include the following types of sampling: stream sediment, shellfish, stream water, leaf litter, and deer. 


\section{CONTENTS}

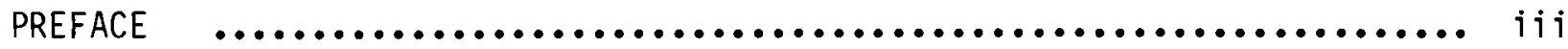

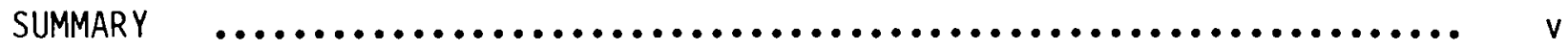

INTRODUCTION................................................ 1

PURPOSE OF THE STUDY................................ 1

SCOPE OF THE STUDY................................ 2

SITE DESCRIPTION......................................... 4

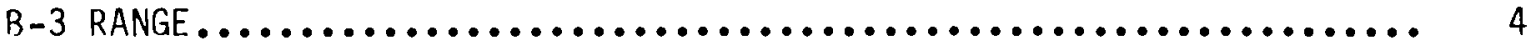

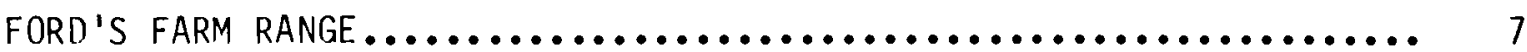

SAMPLING AND ANALYTICAL METHODS $\ldots \ldots \ldots \ldots \ldots \ldots \ldots \ldots \ldots \ldots \ldots \ldots \ldots \ldots \ldots \ldots$

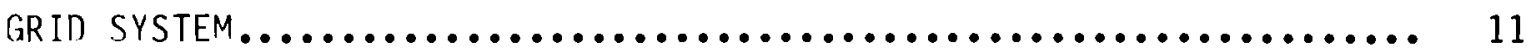

GROUND SURVEY..................................... 12

ENVIRONMENTAL SAMPLING.............................. 12

Soil Samples.................................... 12

Stream Sediment Samples............................... 13

Soil and Stream Sediment Profiles....................... 13

Water Samples..................................... 13

Vegetation Samples................................... 14

Commercial Samples................................ 14

ANALYTICAL METHODS $\ldots \ldots \ldots \ldots \ldots \ldots \ldots \ldots \ldots \ldots \ldots \ldots \ldots \ldots \ldots \ldots \ldots \ldots \ldots \ldots$

Fluorometric Analysis............................... 14

Isotopic Analysis................................. 15

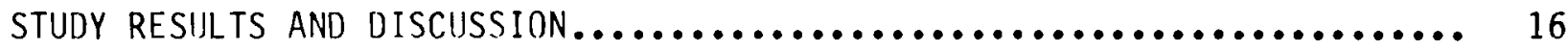

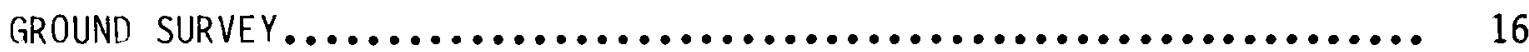


ENVIRONMENTAL SAMPLING............................... 19

Soil Samples and Profiles............................ 19

Stream Sediment Samples and Profiles...................... 21

Water Samples.................................... 25

Vegetation Samples................................ 27

SPECIAL-STUDIES RESULTS.............................. 29

Isotopic-Composition Analysis....................... 29

Dissolution Rate Study............................. 31

Analysis of Dissolved and Suspended Uranium............... 31

Commercial-Sample Analysis........................... 31

RESULTS SUMMARY AND DISCUSSION........................ 32

SUGgESTED STUDIES AND ENVIRONMENTAL-SURVEILLANCE PROGRAM ........... 35

SUGGESTED STUDIES................................. 35

SURVEILLANCE PROGRAM.............................. 36

APPENDIXES

A. AERIAL-SURVEY DATA $\ldots \ldots \ldots \ldots \ldots \ldots \ldots \ldots \ldots \ldots \ldots \ldots \ldots \ldots \ldots \ldots \ldots \ldots \ldots \ldots \ldots \ldots$

B. ANALYTICAL RESULTS OF ENVIRONMENTAL SAMPLING................ B.1

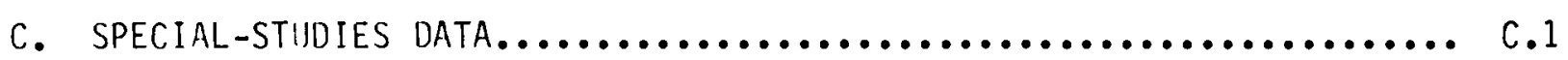




\section{FIGURES}

1 Aberdeen Proving Ground, Maryland....................... 5

2 B-3 Range with Numbered Sampling Sites..................... 6

3 Ford's Farm Range and Surrounding Areas with Numbered Sampling Sites....................................... 8

4 Average Count Rates Around Main-Grid Points, Ford's Farm.......... 17

5 Maximum Count Rates on Main Grid, Ford's Farm................. 18

6 Log-Normal Probability Plots of Soil Sample Data, B-3 Range and Ford's Farm Main Grids....................... 20

7 Uranium Concentrations in Soil Samples, Ford's Farm Main Grid........................................ 22

8 Uranium Concentrations in Stream Sediment Samples, Ford's Farm Main Grid................................... 24

9 Uranium Concentrations in Vegetation Samples, Ford's Farm Main Grid........................................ 28

A.1 Aerial-Survey Plot of the Ford's Farm Range by EG\&G............ A.2

C.1 Dissolution of Uranium Dust in River Water at $10^{\circ} \mathrm{C} \ldots \ldots \ldots \ldots \ldots$

C.2 Dissolution of Uranium Dust in Sea Water at $10^{\circ} \mathrm{C} \ldots \ldots \ldots \ldots \ldots \ldots$ 


\section{$\underline{\text { TABLES }}$}

1 Uranium Concentrations in Soil Profiles from

the Ford's Farm Range......................................

2 Uranium Concentrations in Stream Sediment Profiles

from the B-3 Range and the Ford's Farm Range.................... 26

3 Isotopic-Analysis Results................................. 30

4 Isotopic Weight Percents of Natural and Depleted

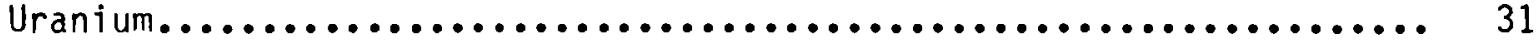

B.1 Uranium Concentrations in All Soil Samples Collected............ B.2

B.2 Uranium Concentrations in All Stream Sediment

Samples Collected......................................... 6

B.3 Uranium Concentrations in All Water Samples Collected............ B.8

B.4 Uranium Concentrations in All Vegetation Samples

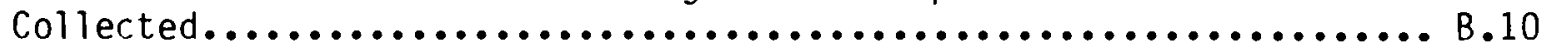

C.1 Sample Data from the Dissolution Rate Study.................... C.2

C.2 Dissolved and Suspended Uranium Concentrations in

Water Samples from the Ford's Farm Range..................... C.4 
ENVIRONMENTAL SURVEY

OF THE B-3 AND FORD'S FARM RANGES

\section{INTRODUCTION}

Over the past 5 years, the Army's weapons testing program has included the firing of depleted-uranium (DU) projectiles into targets at two locations on the Aberdeen Proving Ground, Maryland. At the first location, the Ford's Farm range, approximately $1600 \mathrm{~kg}$ of DU in the form of projectiles have been fired into various types of armor (metal) targets. When the projectiles hit the targets, a particulate DU cloud is released along with fragments of the projectile. At the second location, the B-3 range, approximately $1100 \mathrm{~kg}$ of Du have been fired into soft targets. The projectiles pass through these targets intact and usually burrow into the ground beyond the targets; however, fragmentation into visible pieces is possible if projectiles hit trees or rocks either above or below ground.

The Army is concerned about the fate of the DU in the environment of both areas, and is particularly interested in whether any DU has moved into the Chesapeake Bay near the Aberdeen Proving Ground.

PURPOSE OF THE STUDY

The purpose of the study reported on here was to determine the location of DU around the two target areas. Pacific Northwest Laboratory(a) (PNL) personnel made two trips to the Aberdeen Proving Ground to conduct an environmental survey. The first trip, during the week of March 26, 1978, will be referred to as the early-spring trip; the second, during the week of September 11, 1978, will be referred to as the late-summer trip.

The study is considered a limited environmental survey because the areas surveyed were predetermined, based on information supplied by Aberdeen personnel. This information included 1) an estimate of where most projectiles were

(a) Operated for the Department of Energy by Battelle Memorial Institute. 
landing at the B-3 range and 2) an aerial-survey plot of the Ford's Farm range and the surrounding areas indicating the approximate locations of elevated radiation levels.

\section{SCOPE OF THE STUDY}

The study was limited to a ground survey and the collection of environmental samples from the vicinity of the Ford's Farm and B-3 firing ranges. The ground survey was made using portable radiation detection instruments capable of detecting low-level beta-gamma radiation from DU. Environmental sampling involved the collection of soil, stream sediment, water, and vegetation samples, and analyses of these samples for total uranium.

No effort was made during this study to estimate the natural background levels of uranium in an unaffected area outside the Aberdeen Proving Ground. However, a few samples were collected from a reference location on the Proving Ground that was thought to be unaffected, for comparison with the samples from the range areas. In addition, the uranium concentrations in the samples collected on the Proving Ground were compared with typical environmental levels of uranium as reported in the literature.

Samples of commercial seafood (crab meat) from the Chesapeake Bay were purchased and analyzed for their uranium content as some indication of uranium levels in the bay. These levels can be used as a reference point against which to compare concentrations in similar seafood samples if a continuing environmental surveillance program is begun.

Several special studies were conducted as part of the survey. The isotopic composition of uranium was determined for a limited number of soil and vegetation samples from the B-3 range and Ford's Farm. The activity levels in these samples were compared with activity levels calculated for natural and depleted uranium as a means of estimating the extent of DU spread from the test firings. A dissolution rate study was also done to estimate the relative solubility of DU dust in sea water and river water. 
Details on the sites surveyed, the methods used, and the results of the study follow. The final section of this report includes a discussion of possible studies to further determine the fate of DU in the Aberdeen Proving Ground environment. A routine environmental-survey program is also outlined. 


\section{SITE DESCRIPTION(a)}

The Aberdeen Proving Ground is located approximately $48 \mathrm{~km}$ northeast of Baltimore, Maryland, with the Chesapeake Bay as an eastern border (see Figure 1). The installation consists of approximately 32,100 ha, of which 15,800 ha are covered by water and 16,300 ha are 1 and. The Bush River separates the installation into two main areas: the Aberdeen Area to the east and the Edgewood Area to the west.

Most of the installation's terrain is gently rolling, with much of it left as unimproved land and forrested areas. Elevations range from sea level to approximately $30 \mathrm{~m}$ above sea level.

The Aberdeen Proving Ground is located in the middle latitudes where the general atmospheric flow is from west to east. The predominant wind direction over a year is from the northwest, with an average wind speed of approximately $16 \mathrm{~km} / \mathrm{hr}$. The area has a humid, continental type of climate. Temperatures are generally mild, with a mean low of $-4^{\circ} \mathrm{C}$ in January and a mean high of $30^{\circ} \mathrm{C}$ in July. Precipitation throughout the year is fairly uniform, with an annual mean of around $104 \mathrm{~cm}$. Snowfall is confined to the winter months and averages approximately $56 \mathrm{~cm} / \mathrm{yr}$. The relative humidity reaches its highest monthly average, $70 \%$, in September and its 1owest, $57 \%$, in March.

The environmental survey was conducted at the B-3 range and the Ford's Farm range. Roth areas are east of the Bush River in the Aberdeen Area of the Proving Ground, with the B-3 range about $6 \mathrm{~km}$ northeast of Ford's Farm. The approximate location of each area is shown in Figure 1 .

B-3 RANGE

The B-3 range encompasses a large land area extending approximately $8000 \mathrm{~m}$ downrange from the firing position. On the range, projectiles are fired for accuracy at soft targets positioned 1000, 2000, 3000, and $4000 \mathrm{~m}$ downrange.

(a) General information about the Aberdeen Proving Ground and its climate was provided by the IJ.S. Army Environmental Hygiene Agency, Aberdeen Proving Ground, Maryland. 


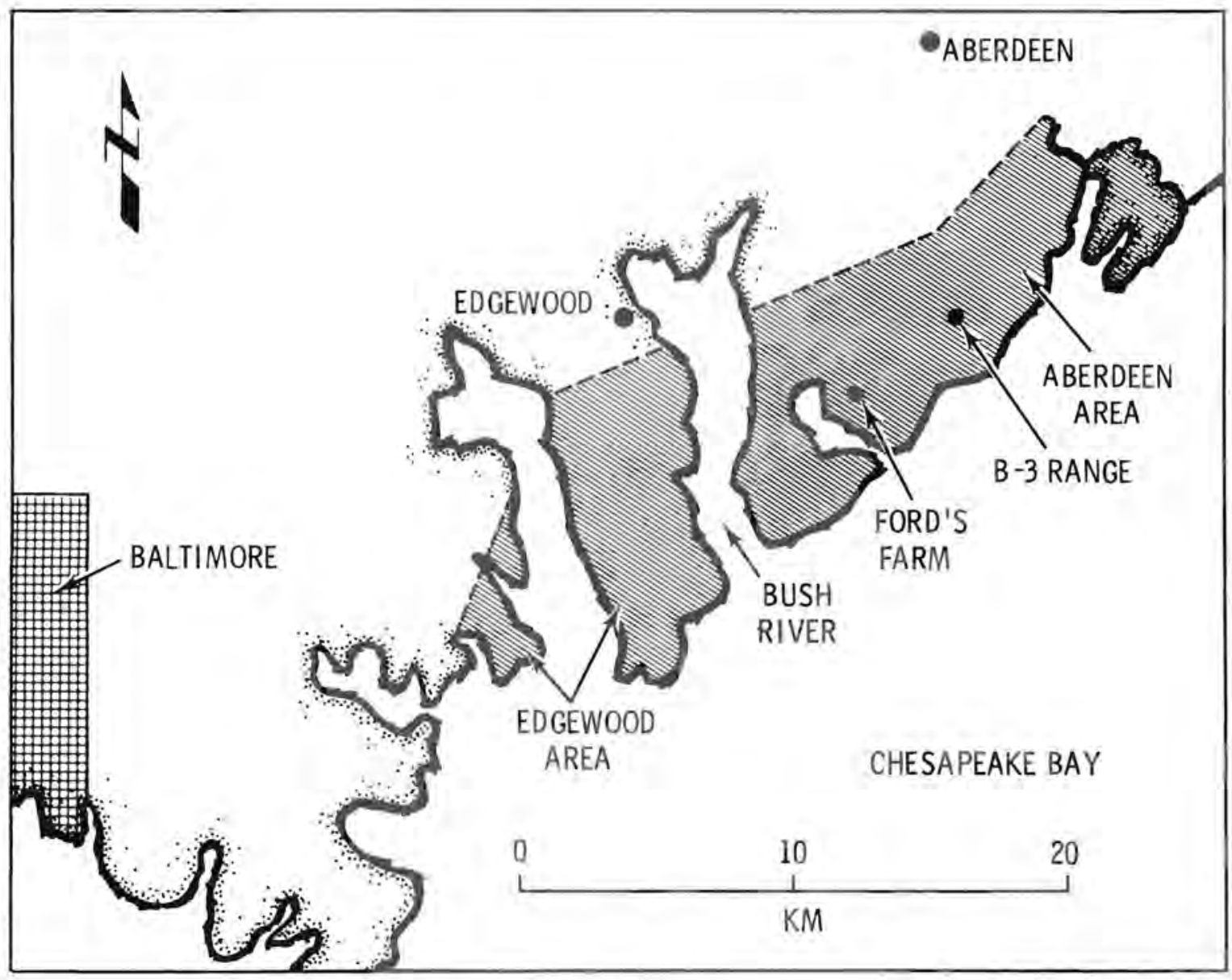

FIGURE 1. Aberdeen Proving Ground, Maryland

Depleted-uranium projectiles are fired at targets $4000 \mathrm{~m}$ downrange on the 4000-meter pad (see Figure 2). These projectiles pass through the targets intact and usually burrow into the ground at locations beyond the target; however, fragmentation into visible pieces is possible if projectiles hit trees or rocks either above or below ground. The intact projectiles or fragments come to rest on the surface or buried underground.

The locations surveyed on the B-3 range were the main grid(a) (Area 1), the beaver dam (Area 2), and the reference area (Area 3), shown in Figure 2.

(a) Both at the B-3 range and at Ford's Farm, an area around the target was gridded off for survey and sampling purposes, as described on page 11. 
C D E F G H I I K L M N O

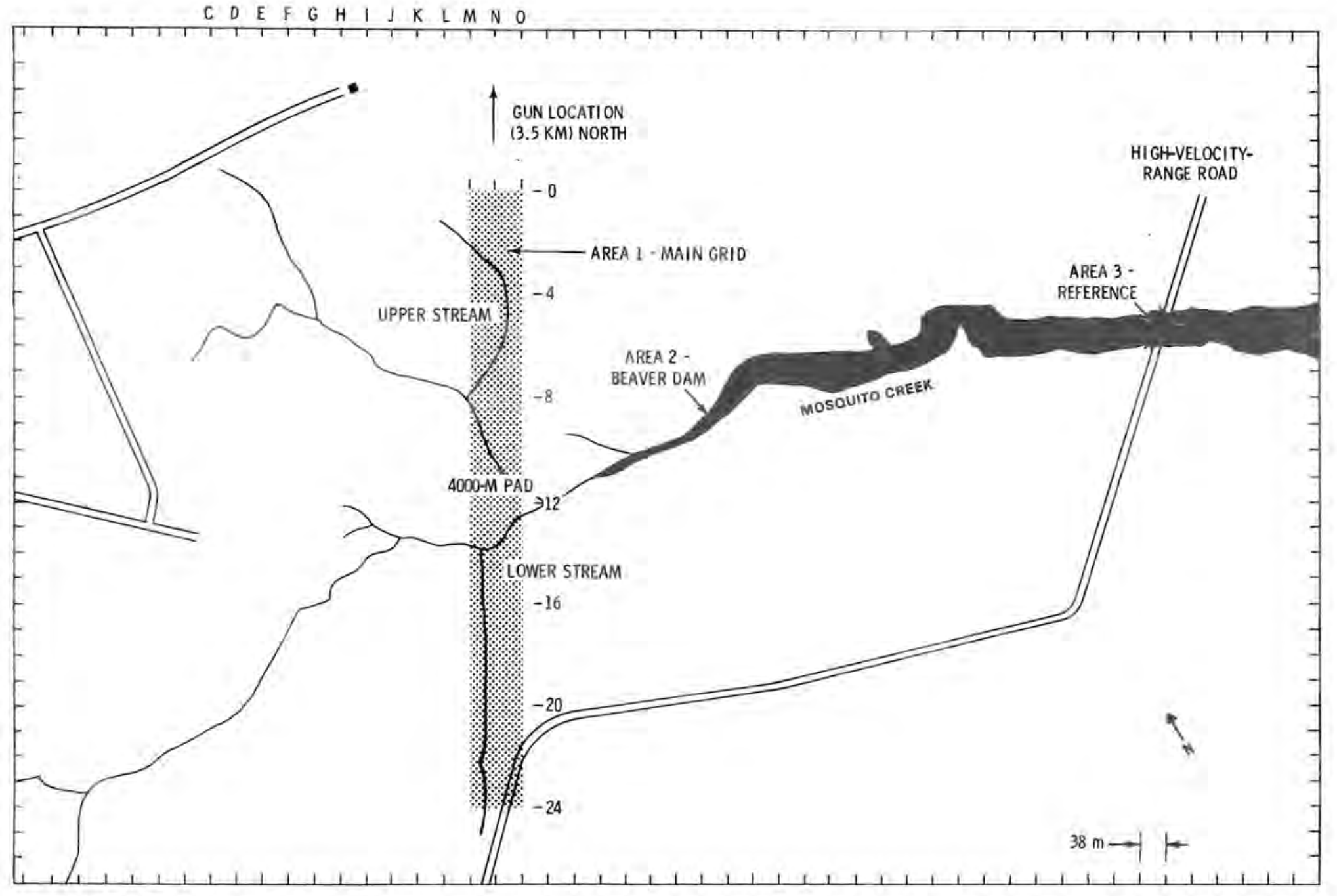

FIGURE 2. B-3 Range with Numbered Sampling Sites 
The main grid was surveyed because Aberdeen personnel estimated that most of the DU projectiles land in this region. This area is drained by several tributaries of Mosquito Creek that join the creek just to the east of the area and flow to the Chesapeake Bay. The beaver dam area, located on Mosquito Creek about $305 \mathrm{~m}$ east of the main grid, was surveyed because the dam would be a prime location for deposition of any suspended DU transported downstream in Mosquito Creek waters. The third area surveyed, the reference area, is approximately $1 \mathrm{~km}$ east of the main grid where a footbridge crosses Mosquito Creek. This area was chosen to represent an unaffected area and provide reference samples for comparison with the samples from Areas 1 and 2 and the Ford's Farm range.

\section{FORD'S FARM RANGE}

At Ford's Farm, DU projectiles are fired $200 \mathrm{~m}$ into metal target plates. The relative positions of the gun and target at Ford's Farm are shown in Figure 3. When the DU projectiles hit the plates, the projectiles fragment and a Dul particulate cloud is released. The cloud drifts from the target and settles on the ground and on nearby vegetation, with the location of the deposition depending on wind and weather conditions. Standard operating procedures require that firing take place only when meteorological conditions will prevent the particulate cloud from drifting back to the gun position where personnel are stationed.

Several tributaries of Bridge Creek drain the target area, as shown in Figure 3. The two tributaries immediately south of the target were extremely swampy during the early-spring trip; however, they were dry, with isolated pockets of standing water during the late-summer trip. Bridge Creek's tributaries meet approximately at the A-A5 Road. The road serves as a dam to the creek, allowing creek water to spill over the road surface. Bridge Creek then flows southwest into Romney Creek, which in turn flows east into the Chesapeake Bay. 


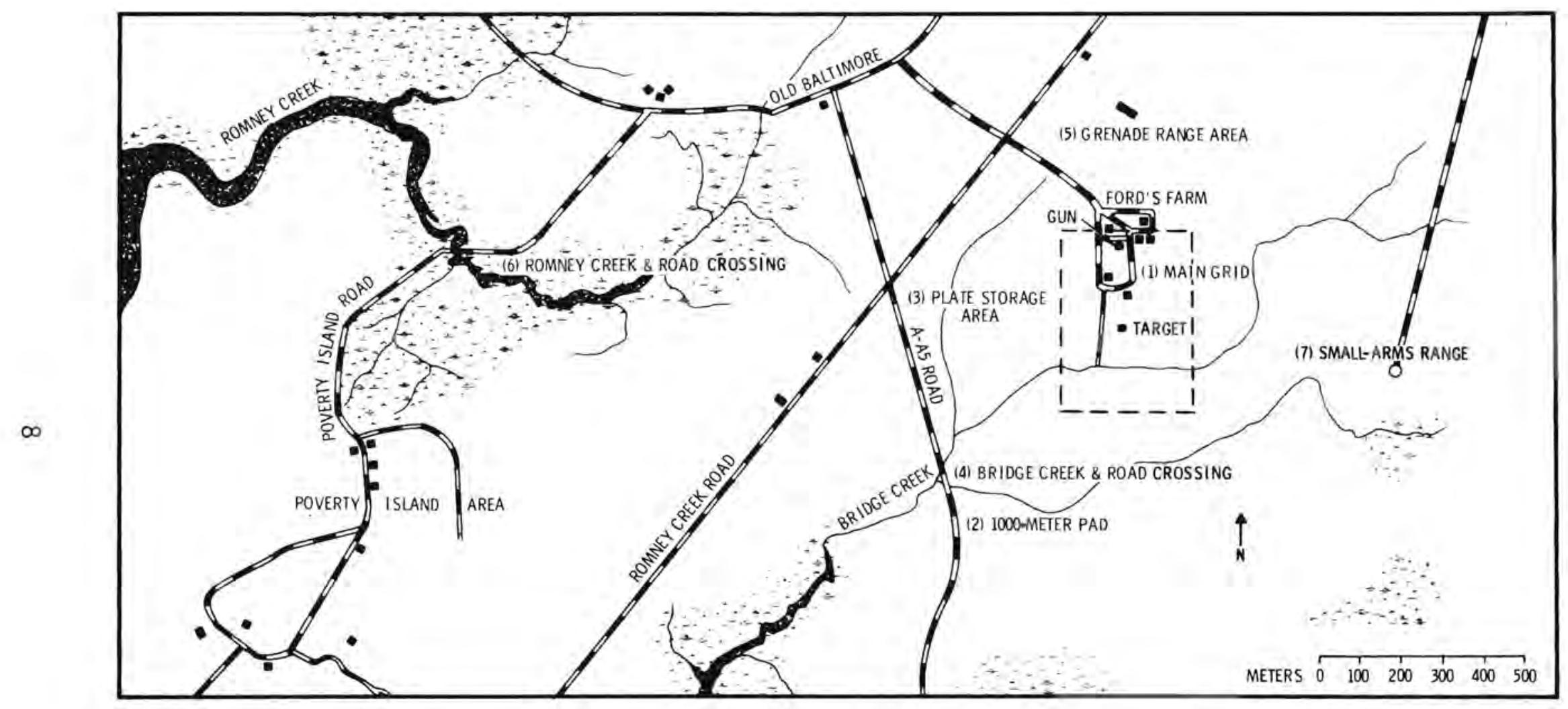

FIGURE 3. Ford's Farm Range and Surrounding Areas with Numbered Sampling Sites 
Seven areas were surveyed in the vicinity of the Ford's Farm range, as shown in Figure 3 and described below:

- Area 1 (the main grid) includes the target area. This area was surveyed during the early-spring trip in an attempt to locate several isopleths shown on the aerial survey plot.(a) It was also surveyed during the late-summer trip because the early-spring survey showed that the highest uranium levels were located in this area.

- Area 2 (the 1000-meter pad) is about $700 \mathrm{~m}$ southwest of the target. This area was surveyed during the early-spring trip in an attempt to locate an isopleth from the aerial-survey plot.

- Area 3 (the plate storage area) is located about $500 \mathrm{~m}$ west of the target. This area was surveyed during the early-spring trip because of the potential for contaminated plates and to search for the location of an isopleth from the aerial-survey plot.

- Area 4 (the Bridge Creek - A-A5 Road crossing) is approximately $600 \mathrm{~m}$ downstream from the target. This area was surveyed during the latesummer trip. It was thought to be a prime location for the deposition of any suspended DU in the creek's water because the road dams the creek at this point, allowing any suspended particles to settle out. Throughout this report, this area will be referred to as the Bridge Creek area.

- Area 5 (the grenade range) is located about $500 \mathrm{~m}$ north of the target. This area surveyed during both the early-spring and latesummer trips as an indicator of the environment upwind from the target.

- Area 6 (the Romney Creek - Poverty Island Road crossing) is approximately $1.6 \mathrm{~km}$ west of the target. This area was surveyed during the late-summer trip because it is near the Poverty Island area, the

(a) See Appendix A for more information on the aerial survey and the location of the isopleths. 
inhabited area closest to the target. Throughout this report, this area will be referred to as the Romney Creek area.

- Area 7 (the small-arms area) is about $700 \mathrm{~m}$ east of the target. This area was surveyed during the early-spring trip in an attempt to locate an isopleth from the aerial-survey plot. 
SAMPLING AND ANALYTICAL METHODS

This section describes the grid systems used in the study, the radiation detection instruments used for the ground survey, the methods of collecting environmental samples, and the techniques used to analyze the samples.

\section{GRID SYSTEM}

Two areas were staked off for the study: the area around the 4000-meter pad on the B-3 range and the area around the Ford's Farm target. The grid systems were used to locate specific areas for ground survey readings and for some environmental sampling. Professional surveyors provided by the Army staked the area during the early-spring trip. The stakes were left in place and used again during the late-summer trip.

The grid area for the B-3 range is referred to as Area 1 or the main grid in Figure 2. The centerline of the grid (Line $N$ ) extends $460 \mathrm{~m}$ north and $460 \mathrm{~m}$ south of the 4000-meter pad and is on the line of fire for all projectiles fired at targets on the pad. Parallel lines were staked off $38 \mathrm{~m}$ to each side of the centerline, making the dimensions of the grid $920 \times 76 \mathrm{~m}$. Surveyors placed wooden stakes every $38 \mathrm{~m}$ on the grid, for a total of 75 stakes or grid points in the $B-3$ range main grid.

The grid area for Ford's Farm is also referred to as Area 1 or the main grid for that area, as shown in Figure 3. This grid was positioned to encompass the large isopleth area around the target in the aerial-survey plot (see Appendix A). The centerline of the grid is parallel to the line of fire and is $460 \mathrm{~m}$ long. The grid was staked off $152 \mathrm{~m}$ to each side of the centerline, making the grid dimensions $460 \times 305 \mathrm{~m}$. Wooden stakes were placed every $38 \mathrm{~m}$ on the grid, for a total of 117 stakes or grid points in the Ford's Farm main grid.

All grid points were labelled using a letter-number system. Lines running north-south were assigned letters and those running east-west were given numbers. 
Ground surveys were conducted using portable survey meters with NE 102 (a) plastic scintillation detectors capable of measuring the low-level beta-gamma radiation of DU. Laboratory calibration of the three detectors used on the trips showed all to read approximately 25,000 counts/min at $5 \mathrm{~cm}$ above a $1-\mathrm{g}$ DU source. This calibration was checked periodically in the field using the same 1-g DU source.

Ground survey readings were taken at all grid points on the B-3 range and Ford's Farm main grids during both survey trips. At each grid point, an area of approximately $1 \mathrm{~m}^{2}$ was surveyed and an average count rate was recorded. The maximum count rate for each $1-m^{2}$ area was also recorded to provide information on the location of any DU fragments in the main grids.

\section{ENVIRONMENTAL SAMPLING}

In the following sections, the methods used in collecting the environmental samples for this study are presented. Samples collected in the main-grid areas of the B-3 range and Ford's Farm were taken at or near the grid points. Soil Samples

Soil samples were collected using a specially designed sampler with a $0.9-\mathrm{m}$ stainless-steel coring tube $5.1 \mathrm{~cm}$ in diameter and $0.17 \mathrm{~cm}$ in wall thickness. The coring tube was pushed into the ground to a depth of $7.6 \mathrm{~cm}$. To minimize cross-contamination, a plastic bag was placed over the end of the tube inserted into the ground. The top of the plastic bag was wrapped around the sutside of the tube. When the tube was pushed into the ground, the soil sample, encased in the plastic bag, was forced into the tube. After the tube was remover, the sample was pulled out, enclosed in the plastic bag, and placed in a wide-mouth jar.

(a) Thorn EMI Gencom Inc. (Nuclear Enterprises), 80 Express St., Plainview, NY 11803. 
Stream Sediment Samples

Stream sediment sampling was performed in a manner similar to soil sampling. Samples were collected near the shoreline unless the stream was narrow enough to permit sampling at its midpoint.

Soil and Stream Sediment Profiles

Soil and stream sediment profiles were taken to check for evidence of vertical movement of uranium in the soil and to determine whether uranium was being buried in stream sediments. Profiles were taken to depths of 7.6, 15.2, and $30.5 \mathrm{~cm}$.

The 7.6-cm profiles were collected in the same manner as the soil and stream sediment samples; however, unlike the samples, the profiles were later divided into increments of 0 to $2.5 \mathrm{~cm}, 2.5$ to $5.1 \mathrm{~cm}$, and 5.1 to $7.6 \mathrm{~cm}$ for analysis.

The $15.2-\mathrm{cm}$ and $30.5-\mathrm{cm}$ profiles were taken with the same coring tube used to collect the soil and stream sediment samples. The coring tube was pushed into the ground to the appropriate depth, then pulled out with the profile inside. The profile was removed from the coring tube and cut into increments of 0 to $7.6 \mathrm{~cm}$ and 7.6 to $15.2 \mathrm{~cm}$ for the $15.2-\mathrm{cm}$ profiles and 0 to $7.6 \mathrm{~cm}, 7.6$ to $15 . ? \mathrm{~cm}, 15.2$ to $22.9 \mathrm{~cm}$, and 22.9 to $30.5 \mathrm{~cm}$ for the $30.5-\mathrm{cm}$ profiles. Each increment was packaged individually before transport to an analytical laboratory.

Water Samples

All water samples were taken by the grab-sampling method. During the early-spring trip, water samples were collected in 350-ml wide-mouth jars. During the late-summer trip, the sample size was increased to $1 \mathrm{~L}$ so that there would be sufficient volume to perform the DU solubility test. These samples were collected in $1-L$ polyethylene bottles.

Samples were collected in the middle of a stream unless the stream's width prevented midstream collection. In this case, samples were taken near the shoreline. 
Vegetation Samples

The vegetation sampled consisted of native grasses and leaf litter. Each sample was collected from an area of about $1 \mathrm{~m}^{2}$ and had a wet weight of about $400 \mathrm{~g}$. Native grasses were clipped at ground level, with all species collected in the $1-m^{2}$ area included in the sample. All samples were placed in polyethylene bags.

Commercial Samples

Crab meat was purchased from a commercial vendor in Havre de Grace, Maryland, about $8 \mathrm{~km}$ northeast of Aberdeen. The crab had been caught locally in the upper Chesapeake Bay.

ANALYTICAL METHODS

Sample analysis was performed by the United States Testing Company, Inc. (UST), Richland, Washington. All environmental samples collected during the two survey trips were analyzed for total uranium using a fluorometric technique. In addition, several soil and vegetation samples were analyzed for isotopic composition $\left({ }^{234} \mathrm{U},{ }^{235} \mathrm{U}\right.$, and $\left.{ }^{238} \mathrm{U}\right)$.

Fluorometric Analysis

Soil, stream sediment, and vegetation samples were prepared for analysis by grinding until the material passed through a 2-mm screen. They were then oven-dried at approximately $115^{\circ} \mathrm{C}$ for 12 hours, and an aliquot of ground sample (approximately $2 \mathrm{~g}$ dry weight) was leached in nitric acid. The crab meat samples were ground but not oven-dried, and a 5-g (wet weight) aliquot was leached in nitric acid. Water samples were prepared by evaporating $200 \mathrm{ml}$ to near dryness and then diluting to $10 \mathrm{ml}$ with $2 \mathrm{~N}$ nitric acid.

All samples were then analyzed for total uranium using a fluorometric technique. The results for soil, stream sediment, vegetation, and crab meat samples were expressed in micrograms ( $\mu \mathrm{g}$ ) of uranium per gram of sample. Water sample results were expressed in $\mu \mathrm{g}$ of uranium per liter of water. All sample concentrations reported have an estimated analytical error of $\pm 35 \%$ unless noted otherwise. 
Isotopic Analysis

The isotopic uranium analys is procedure used by UST involved repeatedly dissolving and wet-ashing approximately $5 \mathrm{~g}$ of dry soil or vegetation sample with concentrated nitric acid and hydrogen peroxide. The samples were then heated in a muffle furnace at $260^{\circ} \mathrm{C}$ for 1 to $1-1 / 2$ hours. Uranium was then extracted into methyl-isobutyl ketone (hexone) in three stages. Next, the hexone extractant was evaporated over water and taken to dryness under a heat lamp. Finally, the dried sample was dissolved in a sulfate buffer and electrodeposited on a stainless steel disc, and isotopes of uranium $\left(234 \mathrm{U}, 235_{U}\right.$, and $238 \mathrm{U}$ ) were determined by pulse height analysis of an alpha diode detector spectrum. All results were expressed in $\mu \mathrm{g}$ of uranium per gram of sample. Multiple analyses of spiked soil and vegetation samples were run in parallel with the test samples, with the average yield of the spike used to correct for losses of uranium from the test samples during analysis. 


\section{STUDY RESULTS AND DISCUSSION}

The results of the ground survey and environmental-sample analyses are presented in this section along with the results of the special studies performed. A discussion of the results follows.

\section{GROUND SURVEY}

The results of the ground survey at the B-3 range main grid were primarily background count rates of 50 to 100 counts/min for both survey trips. During the early-spring trip, one DU fragment was found about $200 \mathrm{~m}$ south of the 4000-meter pad near grid point $\mathrm{N}-17$. The count rate above the fragment was over 100,000 counts/min. On removal of the fragment, the count rate dropped to 50 counts/min or background level.

At the Ford's Farm main grid, the background count rates were also 50 to 100 counts/min during both the early-spring and the late-summer surveys. The average readings for a $1-m^{2}$ area around each grid point and the maximum readings on the grid are shown in Figures 4 and 5 , respectively. On both trips, most elevated readings ( $>150$ counts/min) for average count rate were within a 100-m radius of the target (see figure 4 ). The maximum count rate readings were found as far as $190 \mathrm{~m}$ from the target (see Figure 5) and were attributed to the presence of DU fragments.

Review of the data from the Ford's Farm main grid indicated that the average count rates were generally higher and the distribution of DU fragments was wider during the early-spring survey than during the late-summer survey. These differences are probably due to changing survey conditions and not to the gross movement of DU in the soil. During the early-spring trip, vegetation was matted down from winter snows, which permitted the detector to be held relatively close to the ground. By the time the late-summer survey was taken, the vegetation had grown abundantly and the detector had to be held farther from the ground. Because the radiation intensity registered by a detector varies inversely as the square of the distance from the radiation source, the lower late-summer readings may have resulted in part from the greater ground-todetector distance. Another factor that may have contributed to the lower readings is that the detector used senses low-energy gammas from the surfaces 


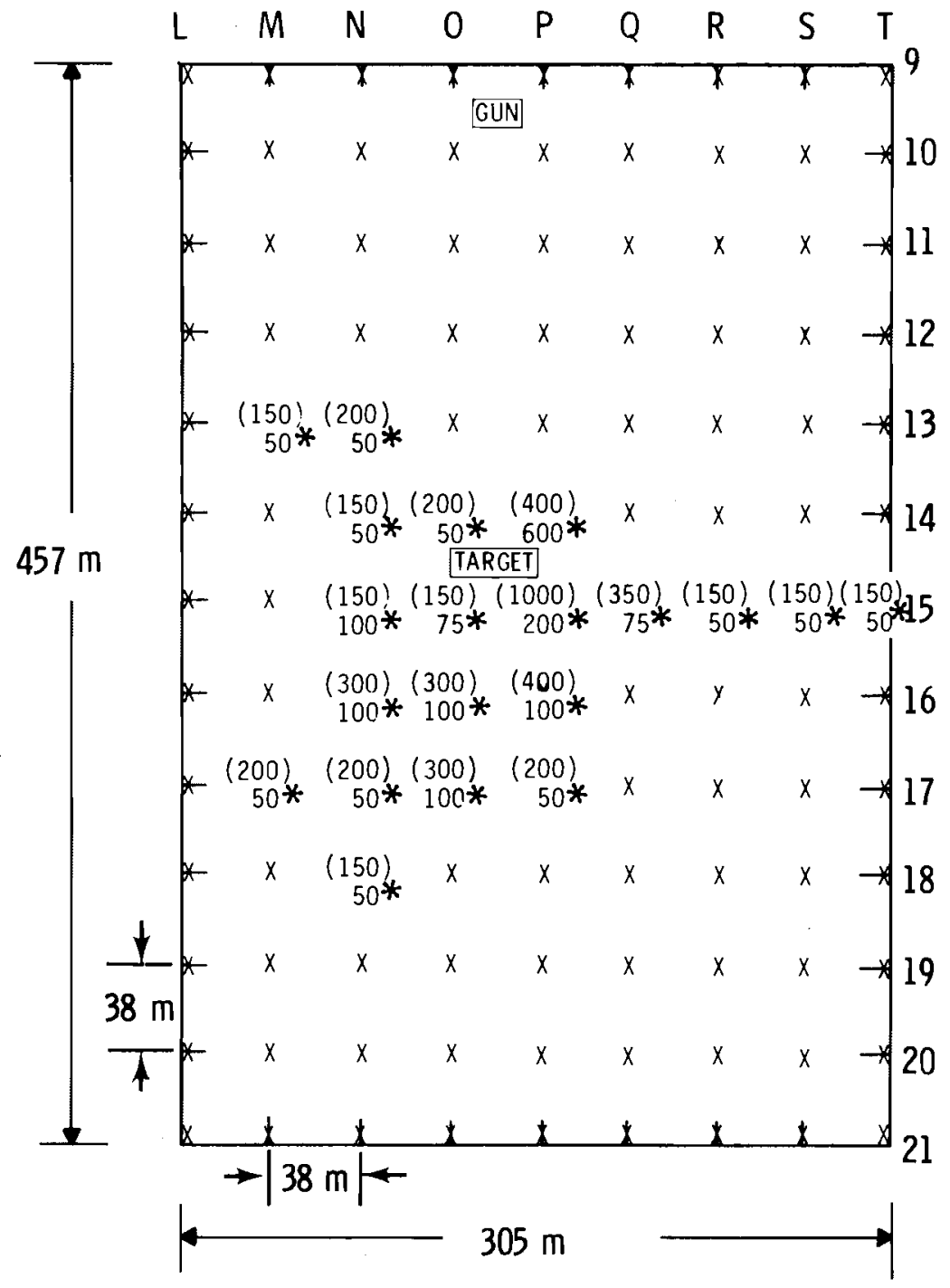

$x \quad 50-100$ COUNTSIMIN ON BOTH SURVEY TRIPS

( ) EARLY-SPRING TRIP

* LATE-SUmmer trip

FIGURE 4. Average Count Rates Around Main-Grid Points, Ford's Farm (counts/min) 


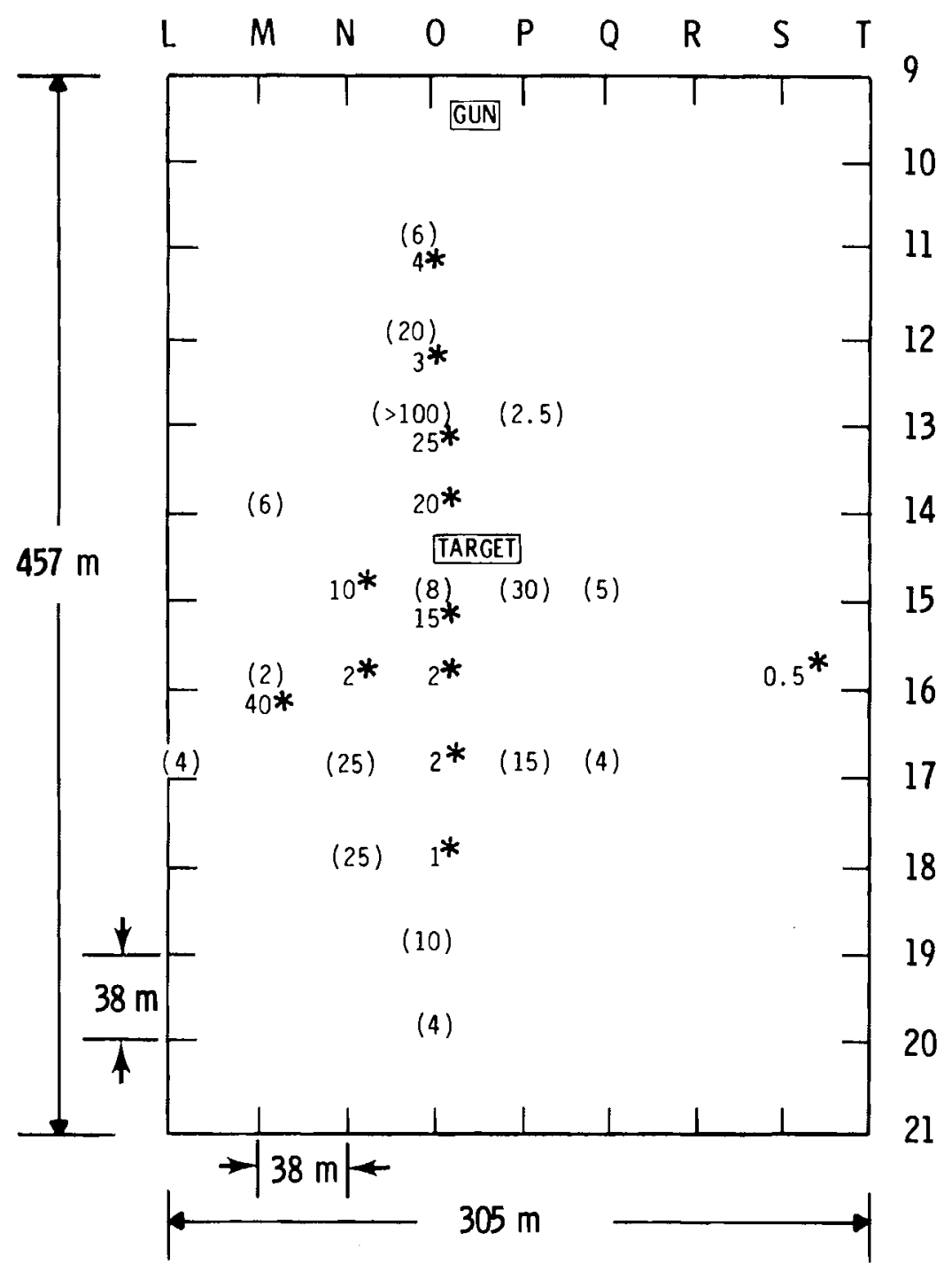

（） EARLY-SPRING TRIP

* LATE-SUMmer TRIP

FIfrIIRE 5. Maximum Count Rates on Main firid, Ford's Farm (1000 counts/min) 
of DU fragments; therefore, any increase in vegetation would have shielded the radiation, yielding lower readings.

Ground survey readings from the small-arms area, plate storage area, and 1000-meter pad in the Ford's Farm range yielded only background count rates of 50 to 100 counts/min. These areas were surveyed only during the early-spring trip.

ENVIRONMENTAL SAMPLING

A complete listing of the analytical results from environmental sampling can be found in Appendix B, Tables B.1 through B.4, along with sample locations. Specific portions of the data are discussed in the following sections. The uranium concentrations found in some samples appeared high relative to other uranium concentrations in the same area. In these cases, the analyses were rerun to determine whether the initial results were valid. Soil Samples and Profiles (Appendix B, Table B.1)

The uranium concentrations found in soil samples, as reported in this section, may be compared with a typical worldwide concentration that ranges from 1 to $4 \mu \mathrm{g} / \mathrm{g}$ and averages $2 \mu \mathrm{g} / \mathrm{g}$ (National Council on Radiation Protection and Measurements 1976).

B-3 Range

Nineteen soil samples from the B-3 range were collected and analyzed. Seventeen were from the main grid (Area 1) and two from the reference area (Area 3 ). Figure 6 is a log-normal probability plot(a) of the soil data.

(a) Log-normal probability plots are useful for cataloguing large amounts of data and providing a first approximation of the similarity of the data. Experience has shown that large numbers of nuclide/media combinations yield a straight line when plotted on log-probability paper. Because the data are represented graphically, the mean, standard deviation, and expected upper limits can readily be seen along with any abnormalities in the data.

Characteristics of special importance in the use of log-normal plots are linearity (denoting data from a common population), standard geometric deviation $(\sigma g$, an indicator of variability or range), and geometric mean ( $x_{g}$, the best estimate of the underlying population mean). The solid-line curves are computer-generated least-squares regression lines (Miller, Fix and Bramson 1977). 


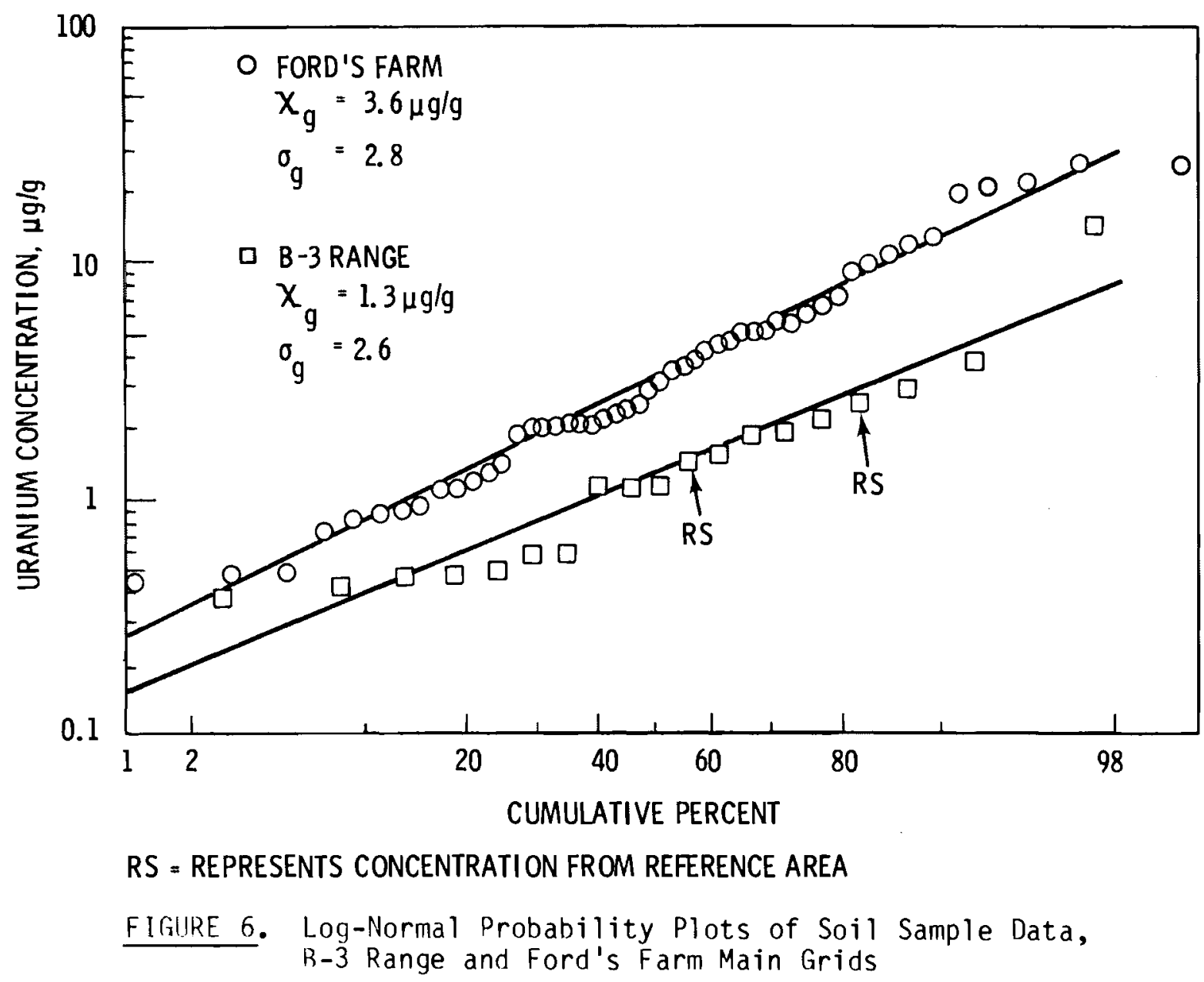

The plot of most of the data points for the soil from the B-3 range approximates a straight line, indicating that these data represent samples from the same population. One outlying point represents sample $\mathrm{N}-17$, collected about $200 \mathrm{~m}$ south of the 4000-meter pad in the area from which a DU fragment was removed. The uranium concentration in the sample was $14 \mu \mathrm{g} / \mathrm{g}$.

The geometric mean, $x_{g}$, taken from the $B-3$ range plot is $1.3 \mu \mathrm{g} / \mathrm{g}$. This number represents the population mean; therefore, the average uranium concentration in the soil of the sampled area is about $1.3 \mu \mathrm{g} / \mathrm{g}$.

The standard geometric deviation, $\sigma_{g}$, is 2.6. This value indicates the range or closeness of individual data points, and would equal 1 if all data points had the same value. 
Plotted points representing the uranium concentrations in the two samples from the reference area $(1.4$ and $2.5 \mu \mathrm{g} / \mathrm{g}) \mathrm{fall}$ on or close to the regression line, indicating that all of the data points probably represent the same population.

\section{Ford's Farm Range}

Sixty soil samples and seven soil profiles from the Ford's Farm range were collected and analyzed. The location of 50 soil samples taken from the main grid and the uranium concentration at each location are shown in Figure 7.

A log-normal probability plot of the 50 samples from the main grid is shown in Figure 6 . The reasonably good fit of individual data points to the regression line again indicates a discrete population $\left(x_{\mathrm{g}}=3.6 \mu \mathrm{g} / \mathrm{g}\right.$ and $\left.\sigma_{\mathrm{g}}=2.8\right)$. The underlying population mean is $3.6 \mu \mathrm{g} / \mathrm{g}$.

Uranium concentrations in soil samples collected at several other locations in the Ford's Farm range (the 1000-meter pad, grenade range, and Romney Creek area) were lower than the concentrations in the reference area samples. Six samples from the grenade range were collected in an area of approximately $1 \mathrm{~m}^{2}$. Analysis of these samples showed a mean uranium concentration and standard deviation of $0.29 \pm 0.12 \mu \mathrm{g} / \mathrm{g}$.

Soil Profiles

Soil profile data for the Ford's Farm range are listed in Table 1. (No profiles were taken on the B-3 range.) Analysis of the $30.5-\mathrm{cm}$ and $7.6-\mathrm{cm}$ profile data indicates that uranium concentrations in soil generally decrease with depth.

Stream Sediment Samples and Profiles (Appendix B, Table B.2)

Uranium concentrations in stream sediments from the B-3 range (main grid and heaver dam) varied from 0.22 to $50 \mu \mathrm{g} / \mathrm{g}$ and were generally lower than the concentrations in the reference samples $(2.0 \mu \mathrm{g} / \mathrm{g})$, as shown in Table B.2. Two exceptions were samples with concentrations of $50 \mu \mathrm{g} / \mathrm{g}$ (collected about $190 \mathrm{~m}$ south of the 4000-meter pad) and $8.2 \mu \mathrm{g} / \mathrm{g}$ (collected about $270 \mathrm{~m}$ south of the 4000-meter pad). Rerun analyses of different aliquots of these samples resulted in levels of $14 \mathrm{\mu g} / \mathrm{g}$ and $2.8 \mathrm{\mu g} / \mathrm{g}$, respectively. 


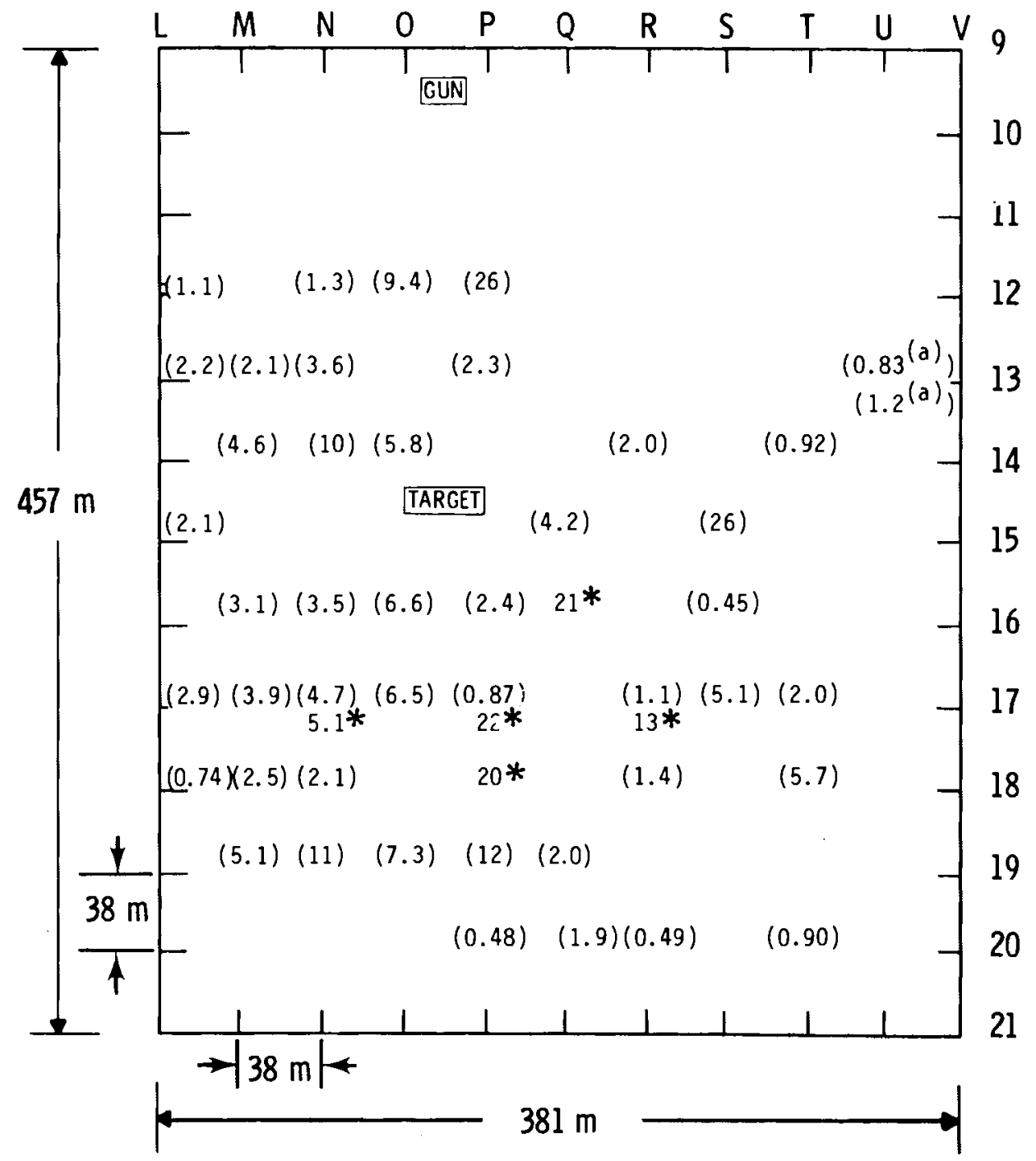

\section{(a) APPROXIMATE GRID LOCATION \\ ( ) EARLY-SPRING TRIP \\ * LATE-SUMmer tRIP}

FIGURE 7. Uranium Concentrations in Soil Samples, Ford's Farm Main Grid ( $\mu \mathrm{g} / \mathrm{g})$

The approximate locations of the 15 stream sediment samples collected in the Ford's Farm main grid and the uranium concentration at each location are shown in Figure 8. The concentrations, also listed in Table B.2, varied from 0.76 to $67 \mu \mathrm{g} / \mathrm{g}$. 
TABLE 1. Uranium Concentrations in Soil Profiles from the Ford's Farm Range

\begin{tabular}{|c|c|c|c|c|c|}
\hline Location & $\begin{array}{c}\text { Position Rel atjive } \\
\text { to Target } \\
\end{array}$ & \multicolumn{4}{|c|}{ Uranium Concentration, $\mu \mathrm{g} / \mathrm{g}(\mathrm{b})$} \\
\hline $30.5-\mathrm{cm}$ Profile & & $0-7.6 \mathrm{~cm}$ & $7.6-15.2 \mathrm{~cm}$ & $15.2-22.9 \mathrm{~cm}$ & $22.9-30.5 \mathrm{~cm}$ \\
\hline Main grid & $38 \mathrm{~m} \mathrm{~S}$ & 81 & 0.10 & 0.98 & 0.37 \\
\hline Main grid & $130 \mathrm{~m} \mathrm{~S}$ & 1.0 & 0.47 & 0.51 & 0.73 \\
\hline 1000-meter pad & & 0.34 & 0.34 & 0.30 & 0.31 \\
\hline Grenade range & & 0.39 & 0.61 & 0.37 & 0.43 \\
\hline
\end{tabular}

$\approx \quad \frac{7.6-\mathrm{cm} \text { Profile }}{\text { Main grid }}$

Main grid $\quad 50 \mathrm{~m} \mathrm{~S}$

Main grid

$250 \mathrm{~m} \mathrm{~S}$

$\begin{array}{ccc}\frac{0-2.5 \mathrm{~cm}}{200} & \frac{2.5-5.1 \mathrm{~cm}}{12} & \frac{5.1-7.6 \mathrm{~cm}}{8.9} \\ 330 & 17 & 7.3 \\ 4.1 & 1.6 & 1.1\end{array}$

(a) For profiles from the main grid.

(b) Uranium concentrations are in $\mu \mathrm{g}$ of uranium per $\mathrm{g}$ of sample with an estimated analytical error of $\pm 35 \%$. 


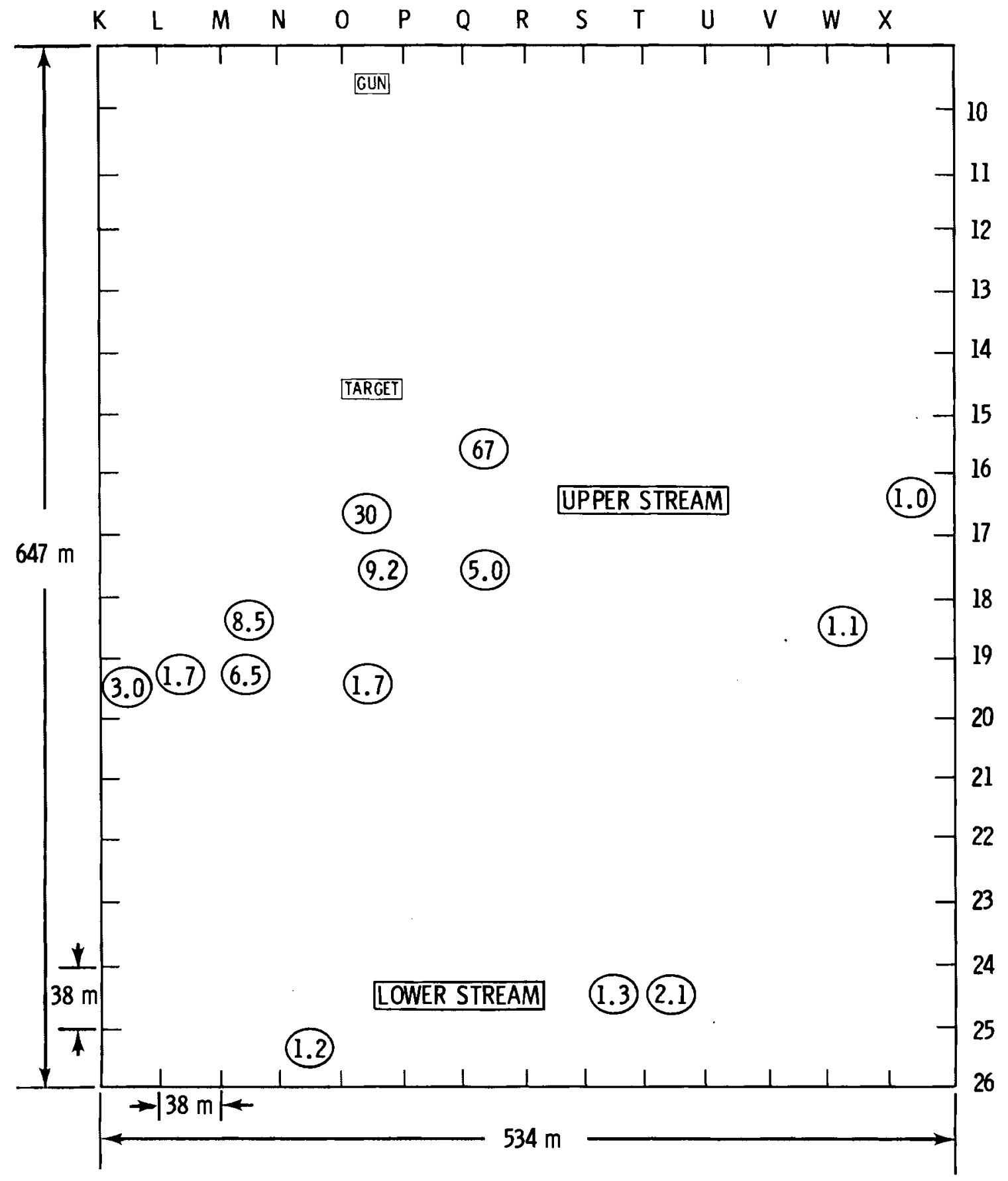

FIGURE 8. Uranium Concentrations in Stream Sediment Samples, Ford's Farm Main Grid $(\mu \mathrm{g} / \mathrm{g}$ ). (The sample containing $0.76 \mu \mathrm{g} / \mathrm{g}$ was located $270 \mathrm{~m}$ west of the grid on line 26.) 
The stream sediment data from the B-3 range and Ford's Farm main grids were assessed using a log-normal probability plot. The samples apparently do not represent a discrete population, as indicated by the wide range of values. It can be concluded from a comparison of the values in Table B.2 that the uranium concentrations in the Ford's Farm main grid are generally higher than those in the $B-3$ range main grid.

Several stream sediment samples were collected at the 1000-meter pad, plate storage area, Bridge Creek area, and grenade range in the area of the Ford's Farm range. The uranium concentrations found in these areas were generally lower than the $2.0-\mu \mathrm{g} / \mathrm{g}$ concentration of the reference area samples, except for one $64-\mu \mathrm{g} / \mathrm{g}$ sample from the Bridge Creek area. When this sample was analyzed again, the result was a concentration of $4.9 \mu \mathrm{g} / \mathrm{g}$.

Stream sediment profile data are presented in Table 2. Similar uranium concentrations were found in all increments analyzed.

Water Samples (Appendix B, Table B.3)

The uranium concentrations in water samples from the $\mathrm{B}-3$ range are listed in Table B.3. The concentrations varied from less than $0.03 \mu \mathrm{g} / \mathrm{L}$ to $43 \mu \mathrm{g} / \mathrm{L}$, with the highest concentrations found in samples from the main-grid area. The concentration range in samples collected during the early-spring trip $(0.10$ to $43 \mu \mathrm{g} / \mathrm{L})$ was greater than the concentration range for the late-summer trip $(<0.03$ to $0.80 \mathrm{Hg} / \mathrm{L})$.

The uranium concentrations in water samples from the Ford's Farm range varied from 0.13 to $59 \mathrm{\mu g} / \mathrm{L}$ (see Table B.3), with the highest concentrations found in samples from the main grid near the target. As at the B-3 range, the range of concentrations in samples from the early-spring trip (3.8 to $59 \mu \mathrm{g} / \mathrm{L})$ was greater than the range in samples from the late-summer trip 0.13 to $16 \mu \mathrm{g} / \mathrm{L})$.

The water sample data for the B-3 range and Ford's Farm were assessed using a log-normal probability plot. The results were inconclusive because the water samples, like the stream sediment samples, apparently do not represent a discrete population. The uranium concentrations of the reference area samples are at the lower end of both the B-3 and Ford's Farm concentration ranges. 
TABLE 2. Uranium Concentrations in Stream Sediment Profiles from the B-3 Range and the Ford's Farm Range

\begin{tabular}{|c|c|c|c|c|c|}
\hline Location & & Uranium & Concentration &,$\mu g / g^{(a)}$ & \\
\hline 7.6-cm Profile & & $0-2.5 \mathrm{~cm}$ & $2.5-5.1 \mathrm{~cm}$ & $5.1-7.6 \mathrm{~cm}$ & \\
\hline $\begin{array}{c}\text { Beaver dam, } \\
\text { B-3 range }\end{array}$ & & 2.3 & 1.5 & 0.88 & \\
\hline $15.2-\mathrm{cm}$ Profile & $0-2.5 \mathrm{~cm}$ & $2.5-5.1 \mathrm{~cm}$ & $5.1-7.6 \mathrm{~cm}$ & $0-7.6 \mathrm{~cm}$ & $7.6-15.2 \mathrm{~cm}$ \\
\hline $\begin{array}{l}\text { Reference area, } \\
\text { B-3 range }\end{array}$ & & & & 2.0 & 2.5 \\
\hline $\begin{array}{l}\text { Reference area, } \\
\text { B-3 range }\end{array}$ & & & & 2.0 & 3.1 \\
\hline $\begin{array}{l}\text { Bridge Creek, } \\
\text { Ford's Farm range }(b)\end{array}$ & 1.5 & 1.9 & 1.3 & & 0.93 \\
\hline
\end{tabular}

(a) Uranium concentrations are in $\mu \mathrm{g}$ of uranium per $\mathrm{g}$ of sample with an estimated analytical error of $\pm 35 \%$.

(b) Special analysis dividing $0-7.6 \mathrm{~cm}$ increment into increments of $0-2.5 \mathrm{~cm}$, 2.5-5.1 cm, and 5.1-7.6 cm. 
Water samples from Ford's Farm have generally higher uranium concentrations than water samples from the B-3 range, as shown by a comparison of the data for the two locations (see Table B.3).

Vegetation Samples (Appendix B, Table B.4)

Uranium concentrations in vegetation samples from the B-3 range and Ford's Farm are listed in Table B.4. An assessment of the data using a log-normal probability plot did not provide conclusive results because the samples contain a wide range of uranium concentrations and apparently do not represent a discrete population. For comparative purposes, typical worldwide concentrations of natural uranium in plants range from $10^{-4}$ to $10^{-1} \mu \mathrm{g} / \mathrm{g}$ (National Council on Radiation Protection and Measurements 1976).

Limited vegetation sampling was done on the $B-3$ range. The concentration of uranium in grass samples ranged from 0.25 to $8.5 \mu \mathrm{g} / \mathrm{g}$, with the concentrations for the three reference area samples falling at the lower end of the range.

Six aliquots of one reference sample were analyzed, and the uranium concentrations were found to range from 0.55 to $2.2 \mu \mathrm{g} / \mathrm{g}$. The mean and standard deviation were $1.6 \pm 0.71 \mu \mathrm{g} / \mathrm{g}$. This standard deviation indicates the degree of variability in concentration expected from analytical errors.

The location of the 28 vegetation samples collected in the Ford's Farm main grid and the uranium concentration at each location are shown in Figure 9. The range of concentrations for grass samples was 1.5 to $1200 \mu \mathrm{g} / \mathrm{g}$, with the highest concentrations within a 76-m radius of the target. Six aliquots of one sample were analyzed. The uranium concentrations found ranged from 390 to $1200 \mu \mathrm{g} / \mathrm{g}$ (see Table B.4), with a mean and standard deviation of $720 \pm 270 \mu \mathrm{g} / \mathrm{g}$.

Several of the reference area samples had uranium concentrations lower than the lower-range limit for the Ford's Farm main grid, indicating that grass in the two areas contains different uranium concentrations. Uranium concentrations in grass samples from the Ford's Farm main grid are generally higher than those from the $B-3$ range. 


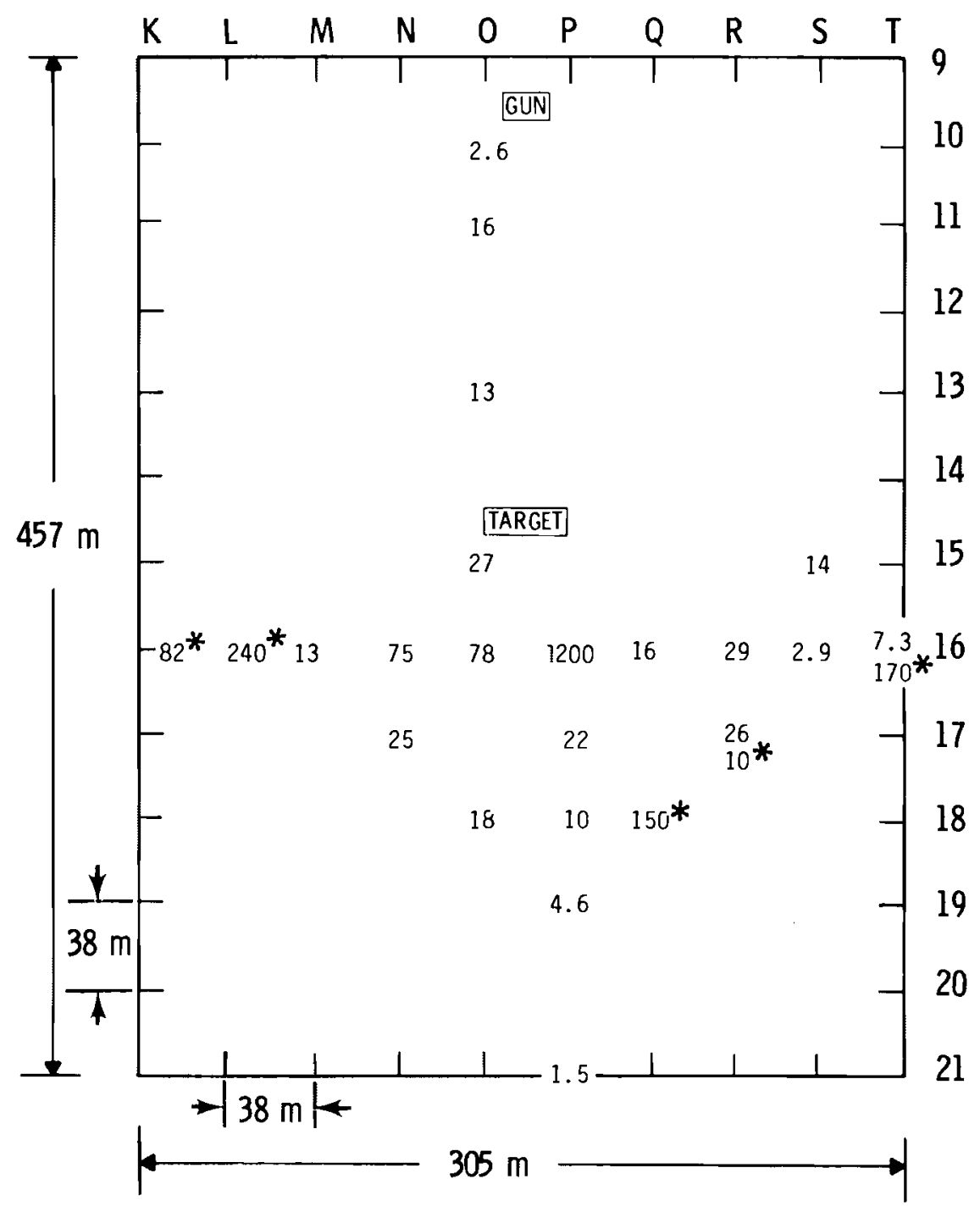

* URANIUM CONCENTRATION IN LEAF LITTER

FIGIJRE 9. Uranium Concentrations in Vegetation Samples, Ford's Farm Main Grid $(\mu \mathrm{g} / \mathrm{g})$. (Note: Three samples were located $76 \mathrm{~m}$ east of the grid on line 13.)

Uranium concentrations in leaf litter samples from the Ford's Farm main grid were variable, ranging from 7.5 to $240 \mu \mathrm{g} / \mathrm{g}$. No leaf litter samples were collected from the reference area for comparison.

Other samples collected from the Ford's Farm range (at the 1000-meter pad, Bridge Creek area, grenade range, and Romney Creek area) contained uranium concentrations ranging from 0.63 to $8.0 \mu \mathrm{g} / \mathrm{g}$ in grass and from 0.93 to $13 \mu \mathrm{g} / \mathrm{g}$ in leaf litter. 
SPECIAL-STUDIES RESULTS

Isotopic-Composition Analysis

Three soil samples and nine vegetation samples from the B-3 range and Ford's Farm were analyzed for uranium isotopic composition. Laboratoryreported analytical results of the ${ }^{234} \mathrm{U},{ }^{235} \mathrm{U}$, and $238 \mathrm{U}$ concentrations in the soil and vegetation samples are listed in Table B.1 and Table B.4, respectively. These results, given in $\mu \mathrm{g} / \mathrm{g}$, were converted to $\mu \mathrm{C}$ of uranium per $\mathrm{g}$ of sample and are listed in Table 3 along with sample locations.

The activity ratio of ${ }^{234} \mathrm{U}$ to ${ }^{238} \mathrm{U}$ was calculated to be approximately 1.1 for natural uranium and approximately 0.1 for depleted uranium. These ratios were computed using the isotopic weight percents listed in Table 4 and the specific activities of ${ }^{234} \mathrm{U}$ and ${ }^{238} \mathrm{U}$. Below are the calculations, assuming $1 \mathrm{~g}$ of natural or depleted uranium:

Natural uranium ratio $=\frac{\left.\mathrm{g}^{234} \mathrm{U} \text { (specific activity }{ }^{234} \mathrm{U}\right)}{\mathrm{a}^{238} \mathrm{U}\left(\text { specific activity }{ }^{238} \mathrm{U}\right)}=\frac{5.7 \times 10^{-5} \mathrm{~g}\left(6.19 \times 10^{-3} \mathrm{Ci} / \mathrm{g}\right)}{0.992739 \mathrm{~g}\left(3.33 \times 10^{-7} \mathrm{Ci} / \mathrm{g}\right)}=1.1$

Depleted uranium ratio $=\frac{\left.\mathrm{q}^{234} \mathrm{U} \text { (specific activity }{ }^{234} \mathrm{U}\right)}{\mathrm{q}^{238} \mathrm{U}\left(\text { specific activity }{ }^{238} \mathrm{U}\right)}=\frac{5.0 \times 10^{-6} \mathrm{~g}\left(6.19 \times 10^{-3} \mathrm{Ci} / \mathrm{g} \text { ) }\right.}{0.9975 \mathrm{~g}\left(3.33 \times 10^{-7} \mathrm{ci} / \mathrm{g} \text { ) }\right.}=0.1$

In a study of ${ }^{234} \mathrm{U} /{ }^{238} \mathrm{U}$ activity ratios for soil and vegetation samples from areas where only natural uranium would be expected to occur, Veselsky (1977) found ratios ranging from 0.878 to 1.062 for soil and from 0.863 to 1.251 for vegetation.

When the activity ratios in Table 3 were compared with the calculated activity ratios for natural and depleted uranium, it was determined that the ratios for all samples from the Ford's Farm main grid, grenade range, and Bridge Creek area and from the reference area indicate the presence of DU. A grass sample from the B-3 range main grid had a ratio more indicative of natural uranium. 
TABLE 3. Isotopic-Analysis Results

$\frac{\text { Sample Number/Location }}{B-3 \text { Range }}$

$\mathrm{N}-21 /$ Main grid

GS-80/Reference area

GS-65/Reference area

\section{Ford's Farm Range}

P-16/Main grid

K-16/Main grid

T-16/Min grid

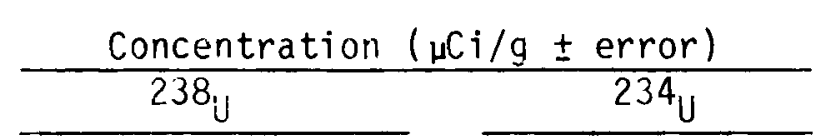

Grass

Grass

Soil

Grass
Leaf litter
Leaf litter
Soil
Grass
Grass
Leaf litter
Soil
Leaf litter

$3.7 E-7 \pm 7.3 E-8(b)$

$3.1 E-7 \pm 6.8 E-8$

$6.5 \mathrm{E}-7 \pm 1.0 \mathrm{E}-7$

$1.1 \mathrm{E}-6 \pm 1.9 \mathrm{E}-7$

$1.5 \mathrm{E}-7 \pm 4.8 \mathrm{E}-8$

$3.6 \mathrm{E}-7 \pm 1.1 \mathrm{E}-7$

$1.4 \mathrm{E}-5 \pm 4.7 \mathrm{E}-7$

$2.0 \mathrm{E}-6 \pm 1.7 \mathrm{E}-7$

$9.0 \mathrm{E}-7 \pm 1.2 \mathrm{E}-7$

$1.1 \mathrm{E}-7 \pm 3.9 \mathrm{E}-8$

$2.3 E-6 \pm 1.9 \mathrm{E}-7$

$2.9 \mathrm{E}-7 \pm 6.8 \mathrm{E}-8$

$1.1 \mathrm{E}-5 \pm 6.0 \mathrm{E}-7$

$1.7 E-6 \pm 2.4 \mathrm{E}-7$

$5.5 \mathrm{E}-7 \pm 9.3 \mathrm{E}-8$

1.6E-7 $\pm 4.9 \mathrm{E}-8$

$2.9 \mathrm{E}-6 \pm 2.2 \mathrm{E}-7$

$3.4 \mathrm{E}-7 \pm 6.8 \mathrm{E}-8$

$2.2 \mathrm{E}-7 \pm 5.6 \mathrm{E}-8$

9. $3 \mathrm{E}-7 \pm 1.7 \mathrm{E}-7$

$8.6 \mathrm{E}-7 \pm 1.7 \mathrm{E}-7$

$9.0 \mathrm{E}-8 \pm 3.6 \mathrm{E}-8$ $\frac{\text { Activity Ratio (a) }}{234 U /^{238} U}$
0.84
0.22
0.34

0.14

0.12

0.13

0.16

0.28

0.12

0.14

0.93

0.15

(a) Activity ratio for natural uranium is approximately 1.1 ; that for depleted uranium is

(b) $3.7 \mathrm{E}-7 \pm 7.3 \mathrm{E}-8=3.7 \times 10^{-7} \pm 7.3 \times 10^{-8}$. 
TABLE 4. Isotopic Weight Percents of Natural and Depleted Uranium

$\begin{array}{ccc}\text { Isotope } & \text { Natural Uranium (a) } & \text { Depleted Uranium(b) } \\ 238_{U} & 99.2739 & 99.75 \\ 235_{U} & 0.7204 & 0.25 \\ 234_{U} & 0.0057 & 0.0005\end{array}$

(a) Reference: Bennellick 1966.

(b) Reference: U.S. Energy Research and Development Administration 1975.

Conflicting results were obtained for the Romney Creek area: the activity ratio for the area's soil sample was 0.94 , indicating that natural uranium was present, while that for the leaf litter sample was 0.15 , indicating the presence of DU.

Dissolution Rate Study

The objective of the dissolution rate study was to estimate the percent of DU dust that would dissolve in sea water and in river water over a 14-day period, given controlled water temperature and a known $\mathrm{pH}$. From the study results, it was concluded that DIJ is quite insoluble in both sea and river water; the approximate dissolution half-times were 4.8 and 6.8 years, respectively. A discussion of the experimental methods and limitations of the study can be found in Appendix $C$.

Analysis of Dissolved and Suspended Uranium

Two water samples were analyzed for dissolved uranium (particles smaller than $0.45 \mu \mathrm{m}$ ) and suspended uranium (particles larger than $0.45 \mu \mathrm{m}$ ). However, the results were inconclusive hecause of the limited number of samples analyzed. The results from the two samples analyzed can be found in Appendix $C$. Commercial-Sample Analysis

The seafood (crab meat) purchased from a commercial vendor in Havre de Grace, Maryland (about $8 \mathrm{~km}$ northeast. of Aberdeen) had been caught locally in the Chesapeake Bay. Because crabs remain fairly stationary, they should be a good indicator of uranium levels in the bay's water-borne sediments. Five 
samples were analyzed and found to contain the following levels of uranium: $0.47 \mu \mathrm{g} / \mathrm{g}, 0.45 \mu \mathrm{g} / \mathrm{g}, 0.36 \mu \mathrm{g} / \mathrm{g}, 0.20 \mu \mathrm{g} / \mathrm{g}$, and $0.21 \mu \mathrm{g} / \mathrm{g}$. The mean and standard deviation are $0.34 \pm 0.13 \mu \mathrm{g} / \mathrm{g}$.

\section{RESULTS SUMMARY AND DISCUSSION}

Based on the ground survey results, the B-3 range main grid and the plate storage area, 1000-meter pad, and small-arms area near Ford's Farm were determined to have only background count rates of uranium (50 to 100 counts/min). The Ford's Farm main grid had some elevated average count rates ( $>150$ counts/ min) within about a $100-\mathrm{m}$ radius of the target. Fragments of DU were found in scattered locations as far as $190 \mathrm{~m}$ from the target. The generally higher average count rates and wider distribution of DU fragments found during the early-spring survey of the Ford's Farm main grid are probably due to changing survey conditions rather than to the movement of DU between the early-spring and late-summer surveys.

Based on a log-normal probability plot of data from soil samples taken at the $R-3$ range and Ford's Farm main grids, the average uranium concentrations for the B-3 range and Ford's Farm were determined to be $1.3 \mu \mathrm{g} / \mathrm{g}$ and $3.6 \mu \mathrm{g} / \mathrm{g}$, respectively. It was concluded from the data that 1) samples collected from these two study areas represent different populations with different average uranium concentrations in the soil; 2) the degree of sampling variability is about the same for each area; and 3) the uranium content of the soil in the B-3 range main grid is similar to that in the reference area, whereas the soil content in the Ford's Farm main grid is higher than that in the reference area. The higher average uranium concentration in the soil of the Ford's Farm main grid may be due to scattered DU fragments from the test firings.

The uranium concentrations found in soil samples from the 1000-meter pad, grenade range, and Romney Creek area near Ford's Farm were lower than the concentrations in the reference area samples, suggesting minimal if any impact from test firings at Ford's Farm.

Based on the soil profile data, it was concluded that uranium concentrations generally decrease with depth. All increments below a depth of $7.6 \mathrm{~cm}$ contained lower uranium concentrations than did the reference area samples. 
The highest concentrations in the top $7.6 \mathrm{~cm}$ of soil were found in the Ford's Farm main grid near the target and may have been due to buried of DU fragments. These limited results indicate no appreciable movement of DU into the soil; however, further study is in order.

The uranium concentrations in stream sediments from the B-3 range and Ford's Farm main grids varied from 0.22 to $50 \mu \mathrm{g} / \mathrm{g}$ and from 0.76 to $67 \mu \mathrm{g} / \mathrm{g}$, respectively. The highest concentrations were found near the target in the Ford's Farm main grid and again are probably attributable to the presence of DU fragments.

Several stream sediment samples were collected downstream from the 4000-meter pad (B-3 range) and the Ford's Farm target. Uranium concentrations in samples from the beaver dam area (about $305 \mathrm{~m}$ downstream from the 4000-meter pad) were about the same as or lower than the $2.0-\mu \mathrm{g} / \mathrm{g}$ concentrations found in the reference area, which indicates that DU has not moved downstream. One sample collected in the Bridge Creek area, about $600 \mathrm{~m}$ downstream from the Ford's Farm target, had a concentration of $64 \mu \mathrm{g} / \mathrm{g}$. Another aliquot from this sample was analyzed and was found to have a concentration of $4.9 \mu \mathrm{g} / \mathrm{g}$, which indicates that DU particles were heterogeneously dispersed in the sample. The possible movement of DU particles in the watercourse should be studied further.

The uranium concentrations found in water samples collected from the B-3 range and Ford's Farm area varied from less than 0.03 to $43 \mu \mathrm{g} / \mathrm{L}$ and from 0.13 to $59 \mu \mathrm{g} / \mathrm{L}$, respectively. Reference area concentrations were generally lower than these values and ranged from 0.12 to $0.20 \mu \mathrm{g} / \mathrm{L}$. As was the case with the soil and stream sediment samples, the highest uranium concentrations in water samples were found in the Ford's Farm main grid near the target. At both the Ford's Farm range and the B-3 range, the highest concentrations were found during the early-spring trip and may be due to the high sediment load in the spring run-off.

These uranium concentrations in water samples are several orders of magnitude lower than the concentrations listed in the U.S. Code of Federal Regulations; 10 CFR 20 states that natural-uranium concentrations in liquid effluents released from a restricted area to an unrestricted area shall not 
exceed $3 \times 10^{-5} \mu \mathrm{Ci} / \mathrm{ml}$. If $3.6 \times 10^{-7} \mathrm{Ci} / \mathrm{g}$ is used for the specific activity of DU, the federally set concentration limit would equal about 83,000 $\mu \mathrm{g} / \mathrm{L}$.

Grass samples collected from the B-3 range and Ford's Farm main grids contained uranium concentrations ranging from 0.25 to $8.5 \mu \mathrm{g} / \mathrm{g}$ and from 1.5 to $390 \mu \mathrm{g} / \mathrm{g}$, respectively. Uranium concentrations in reference area samples ranged from 0.25 to $2.2 \mu \mathrm{g} / \mathrm{g}$. Again, the highest concentrations were found in the Ford's Farm main grid near the target and are probably due to DU fragments in the area.

Based on a limited number of isotopic analyses, most areas sampled were found to have activity ratios close to the calculated 0.1 value for DU. These areas were the Ford's Farm main grid, grenade range, and Bridge Creek area, and the reference area. Therefore, although the uranium concentrations at the Ford's Farm main grid and the reference area appear to be different, it can be concluded from the isotopic analyses that both areas are slightly contaminated with DU.

The activity ratios of two samples (a grass sample from the $B-3$ range main grid and a soil sample from the Romney Creek area) were similar to the activity ratio of natural uranium. However, a leaf litter sample from the Romney Creek area had an activity ratio similar to that of DU. The leaf litter may have blown in from the Ford's Farm range.

It was concluded from the dissolution rate study of DU dust in sea water and river water that DU is relatively insoluble in both, with a dissolution half-time of 4.8 years in sea water and 6.8 years in river water. 


\section{SUGGESTED STUDIES AND ENVIRONMENTAL-SURVEILLANCE PROGRAM}

It was concluded, based on the results of the environmental survey of the B-3 range and the Ford's Farm range, that several additional studies are necessary to determine in detail the extent of DU movement from the two areas. In this section, possible studies are discussed briefly, along with suggestions for a routine environmental-surveillance program for the firing ranges.

\section{SUGGESTED STUDIES}

- Determination of Regional Uranium Background Level - Sampling of background areas representative of the region is necessary for determining the uranium concentrations in environmental samples for comparison with the uranium concentrations in samples collected on the Proving Ground. The areas sampled should be located off the Proving Ground in several directions. The type of samples collected should include soil, stream sediments, water, and vegetation; samples of deer and shellfish would also be useful. All samples should be analyzed for total uranium. Isotopic analyses should be done on a portion of the samples as a means of determining the variation in isotopic composition among sampling areas and individual sample types.

- Soil Characterization - This study would involve extensive soil sampling around the Ford's Farm target area (in the main grid) to aid in estimating the inventory of DU in the area and the degree of spread from the immediate target area.

- Air Sampling - Continuous air sampling for a year or more at the Poverty Island area and the personnel area on Ford's Farm just north of the gun position is suggested. The sampler results from the personnel area would be used to determine the airborne uranium concentrations to which workers may be exposed from test firings. The sampler results from the Poverty Island area would be used to determine the uranium concentrations in the air at the continuously inhabited area nearest the Ford's Farm target. 
- Stream Sediment Characterization - Extensive stream sediment sampling at the mouths of Bridge, Romney, and Mosquito Creeks is suggested as a means of determining whether DU deposits exist at these locations and whether any deposits may be moving offsite. The samples should be analyzed for total uranium; if concentrations significantly higher than the background level are found, the isotopic composition should be analyzed.

- Shellfish Characterization - Extensive shellfish sampling near the mouths of Romney and Mosquito Creeks is suggested. Because shellfish (clams and oysters) are filter-feeders and relatively stationary, they are expected to be good indicators of uranium levels in the Chesapeake Bay's suspended sediments. They also represent the major food pathway leading to man. Sampling locations should be determined from site-specific information because water currents, salinity, and temperature gradients can affect the distribution of shellfish and the movement of surface water from the Proving Ground into the bay.

\section{SURVEILLANCE PROGRAM}

The major objectives of a routine environmental-surveillance program for the Aberdeen Proving Ground would be to evaluate long-term trends of uranium concentrations in the environment, to detect rapid changes in those concentrations, and to define and monitor pathways leading to potentially significant human exposures. All samples should be chemically analyzed for total uranium, and samples with concentrations significantly higher than the background level should also be analyzed for isotopic composition.

Sampling of the following substances might be included in a surveillance program:

- Stream Sediments - Stream sediment samples should be collected at least annually at the mouths of Bridge, Romney, and Mosquito Creeks, with the results compared with background concentrations and the concentrations from the stream sediment characterization study described previously. 
- Shellfish - Shellfish should be collected at least annually at appropriate locations near the Romney and Mosquito Creek estuaries. Analytical results can be compared with background concentrations as well as with concentrations found in the shellfish characterization study mentioned previously.

- Stream Water - Two locations for sampling surface water should be established: one on Bridge Creek, which drains the Ford's Farm target area, and one on Mosquito Creek, which drains the B-3 range. The ideal method for collecting and analyzing water samples would be to use a continuous proportional sampler and to perform monthly sample analyses. An acceptable alternative would be to collect weekly grab samples that would be composited and analyzed monthly. If the amount of uranium leaving the area via the stream water was to be estimated, the rate of stream flow would have to be known or estimated. In addition, any existing wells in the B-3 range and the Ford's Farm range should be evaluated to assess whether the collection and analysis of ground water samples is warranted.

- Leaf Litter - At several locations around the B-3 range and Ford's Farm, leaf litter collection stations should be established for annual sample collection and analysis. Analyses of these samples for uranium can be used to assess the general level of DU contamination and the areal distribution for the previous year of operation. For comparative purposes, annual results would again need to be compared with regional background levels.

- Deer - Several deer should be collected annually, either hunted with special permission or taken as available from road or winter kill. The kidney and the liver tissues should be analyzed for total uranium content. 
Bennellick, E. S. 1966. A Review of the Toxicology and Potential Hazards of Natural, Depleted and Enriched Uranium. AHSB(RP) R58, United Kingdom Atomic Energy Authority, Authority Health and Safety Branch, Harwell, Didcot, Berkshire.

Code of Federal Regulations. Title 10, Part 20, "Standards for Radiation Protection."

Miller, M. L., J. J. Fix and P. E. Bramson. 1977. Radiochemical Analyses of Soil and Vegetation Samples Taken from the Hanford Environs, 1971-1976. BNWL-2249, Pacific Northwest Laboratory, Richland, Washington.

National Council on Radiation Protection and Measurements. 1976. Environmental Radiation Measurements. NCRP 50, Washington, D.C.

U.S. Energy Research and Development Administration. 1975. Conference on Occupational Health with Uranium, April 28-30, 1975. ERDA-93, washington, n.C.

Veselsky, J. C. 1977. "The Isotopic Composition of Uranium in Soils and Plants from the Environment of Seibersdorf, Lower Austria." Radiochem. Radioanal. Letters 30(3):193-198. 
APPENDIX A

AER I AL-SURVEY DATA 


\section{AERIAL-SURVEY DATA}

The aerial survey of the Ford's Farm range was conducted by EG\&G. The EG\&G personnel involved in the survey were contacted by PNL personnel following the early-spring survey trip. (a) They indicated that the survey had been provided to Aberdeen without charge and that the results of the survey were not considered conclusive because the newly acquired equipment that had been used had not been thoroughly checked and calibrated. Hence, no quantitative guidance on contamination concentration categories A, B, C, etc. (Figure A.1) was given. No soil sampling cross checks were done by EG\&G.

Because EG\&G did not ground-proof the aerial data, the ground survey data presented in this report should be used as a substitute.

(a) Personal communication between D. A. Waite and L. Franks, EG\&G, Santa Barbara, CA. 


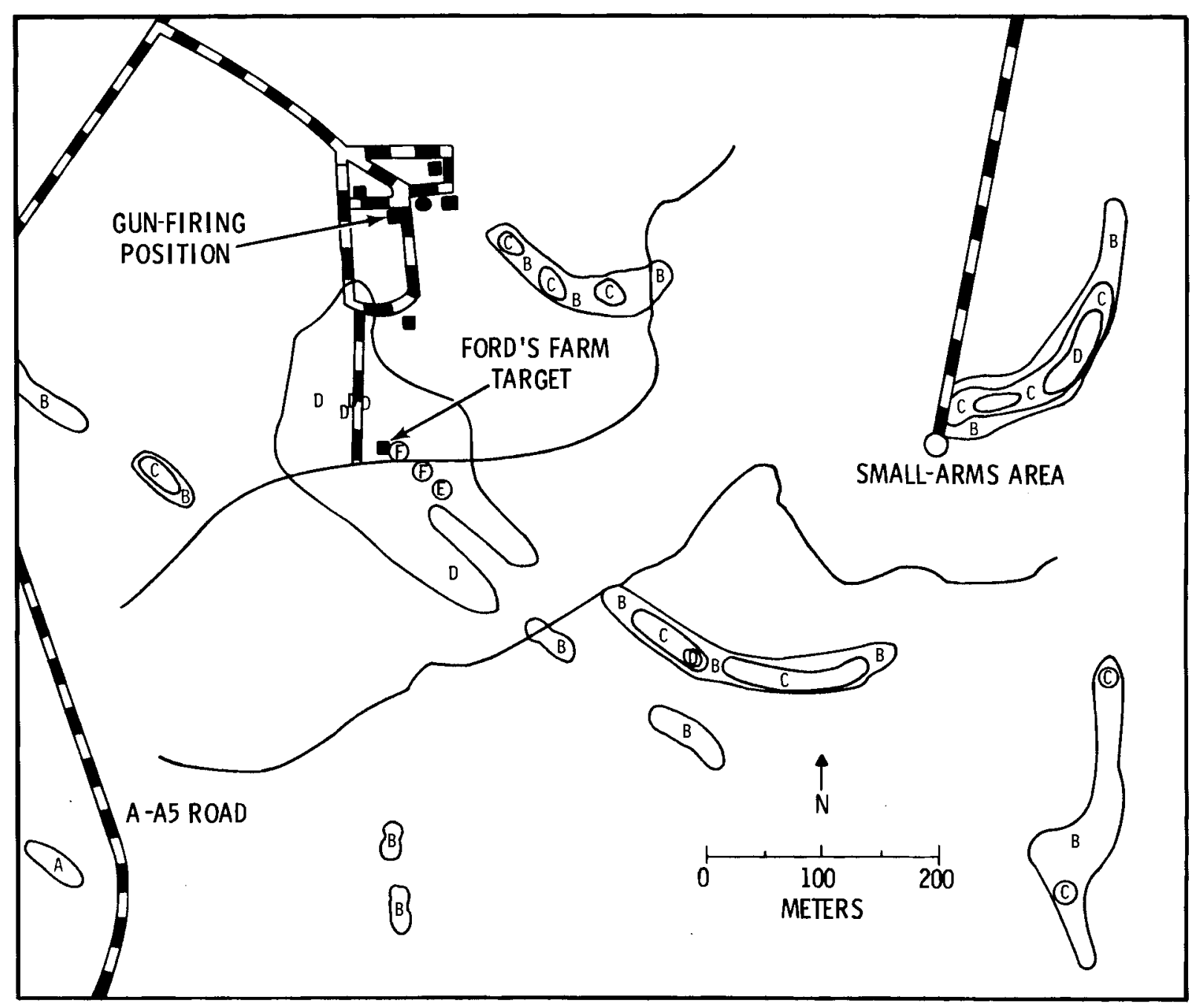

FIGURE A.1. Aerial-Survey Plot of the Ford's Farm Range by EG\&G 
APPENDIX B

ANALYTICAL RESULTS OF ENVIRONMENTAL SAMPLING 


\section{ANALYTICAL RESULTS OF ENVIRONMENTAL SAMPLING}

This appendix presents a complete listing of the environmental-sampling data from the study. Uranium concentrations in soil samples, with sample locations and the trip on which the samples were collected, are presented in Table B.1. Stream sediment, water, and vegetation results can be found in Tables B.2, B.3, and B.4, respectively.

In Tables B.1 through B.4, each sample designation consisting of a letter followed by a number (e.g., A-1) represents the grid point at which the sample was collected. Using the grid point, the approximate collection location can be found by referring to the appropriate map in the main body of the report. $A$ sample designation that consists of two letters preceding a number (e.g., JA-1) is simply an identification number and does not indicate a location. 
TABLE B.1. Uranium Concentrations in All Soil Samples Collected

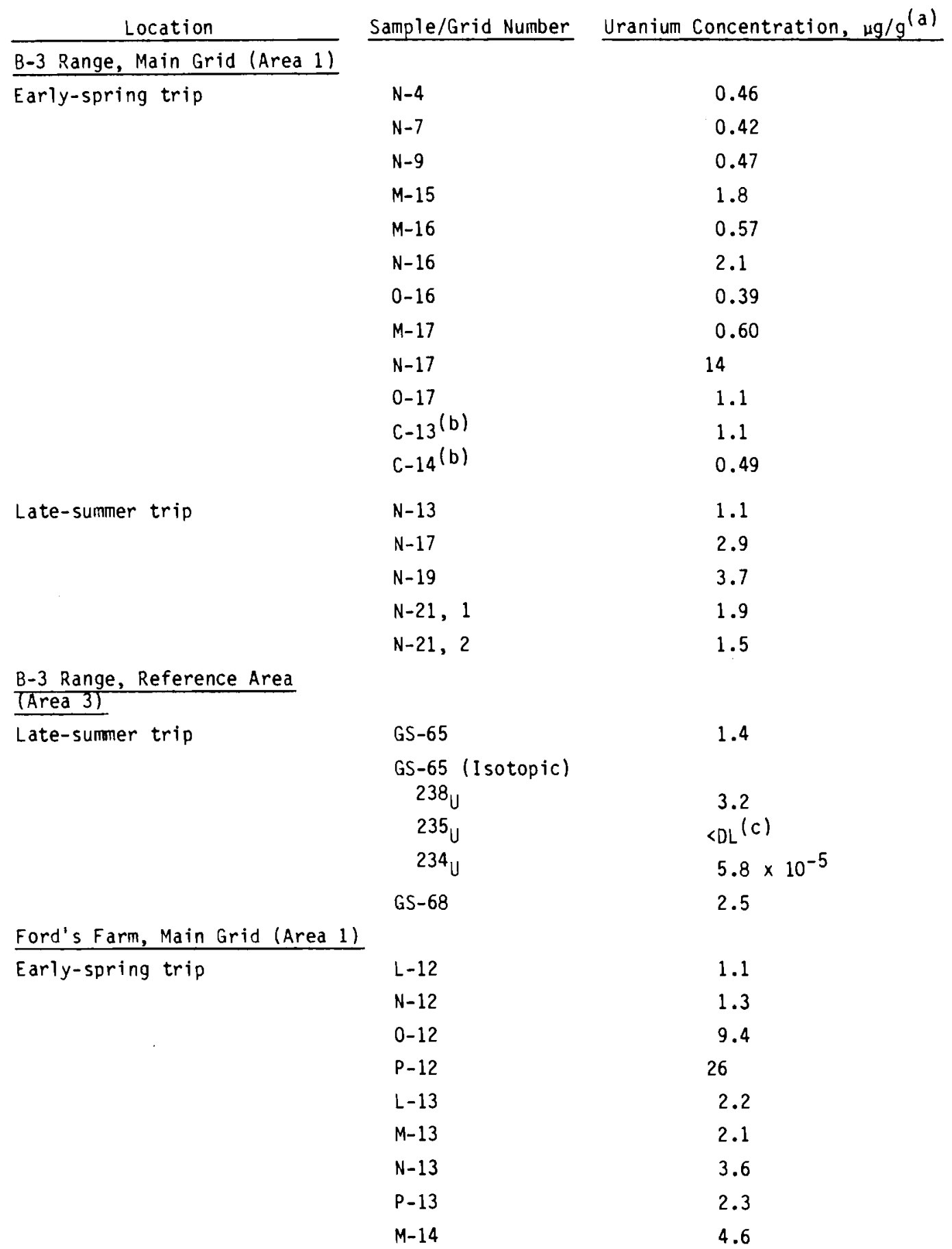

(a) Concentrations are in $\mu g$ of uranium per $g$ of sample, with an estimated analytical error of $\pm 35 \%$.

(b) Collected upstream from the main grid.

(c) Less than detection level, indicating an estimated analytical error greater than $100 \%$. 
TABLE B.1. (contd)

\begin{tabular}{|c|c|c|}
\hline Location & Sample/Grid Number & Uranium Concentration, $\mu g / g(a)$ \\
\hline & $N-14$ & 10 \\
\hline & $0-14$ & 5.8 \\
\hline & $R-14$ & 2.0 \\
\hline & $T-14$ & 0.92 \\
\hline & $L-15$ & 2.1 \\
\hline & Q-15 & 4.2 \\
\hline & s-15 & 26 \\
\hline & $v-13^{(b)}$ & 0.83 \\
\hline & $v-13^{(b)}$ & 1.2 \\
\hline & $M-16$ & 3.1 \\
\hline & $N-16$ & 3.5 \\
\hline & $0-16$ & 6.6 \\
\hline & $P-16$ & 2.4 \\
\hline & S-16 & 0.45 \\
\hline & $L-17$ & 2.9 \\
\hline & $M-17$ & 3.9 \\
\hline & $N-17$ & 4.7 \\
\hline & $0-17$ & 6.5 \\
\hline & $P-17$ & 0.87 \\
\hline & $\mathrm{R}-17$ & 1.1 \\
\hline & S-17 & 5.1 \\
\hline & $T-17$ & 2.0 \\
\hline & $L-18$ & 0.74 \\
\hline & $M-18$ & 2.5 \\
\hline & $N-18$ & 2.1 \\
\hline & $R-18$ & 1.4 \\
\hline & $T-18$ & 5.7 \\
\hline & $M-19$ & 5.1 \\
\hline & $N-19$ & 11 \\
\hline & $0-19$ & 7.3 \\
\hline & $P-19$ & 12 \\
\hline & $Q-19$ & 2.0 \\
\hline & $P-20$ & 0.48 \\
\hline & $Q-20$ & 1.9 \\
\hline & $R-20$ & 0.49 \\
\hline & $T-20$ & 0.90 \\
\hline
\end{tabular}

(a) Concentrations are in $\mu g$ of uranium per $g$ of sample, with an estimated analytical error of $\pm 35 \%$.

(b) Collected from fringe areas of the main grid. 
TABLE B.1. ( contd)

Location

Late-summer trip

Ford's Farm, 1000-Meter Pad TÁrea 2)

Early-spring trip
Sample/Grid Number Uranium Concentration, $\mu \mathrm{g} / \mathrm{g}(\mathrm{a})$ $0-16$ (Profile)

$$
0-7.6 \mathrm{~cm}
$$

$7.6-15.2 \mathrm{~cm}$

81

$15.2-22.9 \mathrm{~cm}$

$22.9-30.5 \mathrm{~cm}$

$\mathrm{N}-18$ (Profile)

$0-7.6 \mathrm{~cm}$

$7.6-15.2 \mathrm{~cm}$

$15.2-22.9 \mathrm{~cm}$

$22.9-30.5 \mathrm{~cm}$

Q-16

Q-16 (I sotopic)

$238_{\mathrm{U}}$

$235_{\mathrm{U}}$

$234_{U}$

N-17

$P-17$

R-17

$P-18$

Q-15 (Profile)

$0-2.5 \mathrm{~cm}$

$2.5-5.1 \mathrm{~cm}$

$5.1-7.6 \mathrm{~cm}$

P-16 (Profile)

$0-2.5 \mathrm{~cm}$

$2.5-5.1 \mathrm{~cm}$

$5.1-7.6 \mathrm{~cm}$

P-21 (Profile)

$0-2.5 \mathrm{~cm}$

$2.5-5.1 \mathrm{~cm}$

$5.1-7.6 \mathrm{~cm}$

$M P-1$

MP-2 (Profile)

$0-7.6 \mathrm{~cm}$

$7.6-15.2 \mathrm{~cm}$

$15.2-22.9 \mathrm{~cm}$

$22.9-30.5 \mathrm{~cm}$
0.10

0.98

0.37

1.0

0.47

0.51

0.73

21

31

0.11

$2.8 \times 10^{-4}$

5.1

22

13

20

200

12

8.9

330

17

7.3

4.1

1.6

1.1

0.41

0.34

0.34

0.30

0.31

(a) Concentrations are in $\mu g$ of uranium per $g$ of sample, with an estimated analytical error of $\pm 35 \%$.

$$
\text { B. } 4
$$




\section{TABLE B.1. (contd)}

Location

Ford's Farm, Grenade Range

(Area 5)

Early-spring trip
Sample/Grid Number Uranium Concentration, $\mu g / g^{(a)}$

$\begin{array}{ll}\text { GR-1 } & 0.19 \\ \text { GR-2 } & 0.20 \\ \text { GR-3(b) } & 0.19 \\ \text { GR-4 } & 0.30 \\ \text { GR-5 } & 0.18 \\ \text { GR-6 } & 0.25 \\ \text { GR-7 } & 0.29 \\ \text { GR-8 } & 0.51 \\ \text { GR-9 (Profile) } & \\ 0-7.6 \mathrm{~cm} & 0.39 \\ 7.6-15.2 \mathrm{~cm} & 0.61 \\ 15.2-22.9 \mathrm{~cm} & 0.37 \\ 22.9-30.5 \mathrm{~cm} & 0.43\end{array}$

Ford's Farm, Romney Creek (Area 6)

Late-sumner trip
PI -1

PI-1 (Isotopic) $238_{U}$

$235_{U}$

$234 \mathrm{U}$
1.1

2.8

$\angle D L(c)$

(a) Concentrations are in $\mu g$ of uranium per $g$ of sample, with an estimated analytical error of $\pm 35 \%$.

(b) Samples GR-3 through GR-8 were all collected in an area of approximately $1 \mathrm{~m}^{2}$.

(c) Less than detection level, indicating an estimated analytical error greater than $100 \%$. 
TABLE B.2. Uranium Concentrations in A11 Stream Sediment Samples Collected

\begin{tabular}{|c|c|c|}
\hline \multirow{2}{*}{\multicolumn{2}{|c|}{$\frac{\text { Location }}{\text { B-3 Ranae Main Grid Lrea } 11}$}} & Uranium Concentration, $\mu \mathrm{g} / \mathrm{g}^{(\mathrm{a})}$ \\
\hline & & B-3 Range, Main Grid (Area 1) \\
\hline \multirow[t]{17}{*}{ Early-spring trip } & $\mathrm{N}-2$ & 0.68 \\
\hline & $0-4$ & 0.42 \\
\hline & $M-7$ & 0.69 \\
\hline & $0-6$ & 0.48 \\
\hline & $M-17$ & $50 \quad(14)^{(b)}$ \\
\hline & $M-18$ & 1.9 \\
\hline & $M-19$ & $8.2(2.8)^{(b)}$ \\
\hline & $M-20$ & 0.22 \\
\hline & $M-21$ & 2.5 \\
\hline & $M-22$ & 1.1 \\
\hline & $N-23$ & 0.38 \\
\hline & $G-4(c)$ & 1.4 \\
\hline & $H-5^{(c)}$ & 0.42 \\
\hline & $I-6^{(c)}$ & 0.58 \\
\hline & $\mathrm{J}-7^{(c)}$ & 2.4 \\
\hline & $k-7^{(c)}$ & 0.30 \\
\hline & $c-21(c)$ & 0.68 \\
\hline \multicolumn{3}{|c|}{ B-3 Range, Beaver Dam (Area 2) } \\
\hline \multirow[t]{5}{*}{ Late-summer trip } & GS-5 & 0.87 \\
\hline & GS-6 (Profile) & \\
\hline & $0-2.5 \mathrm{~cm}$ & 2.3 \\
\hline & $2.5-5.1 \mathrm{~cm}$ & 1.5 \\
\hline & $5.1-7.6 \mathrm{~cm}$ & 0.88 \\
\hline \multicolumn{3}{|c|}{$\frac{\text { B-3 Range, Reference Area }}{(\text { Area 3) }}$} \\
\hline \multirow[t]{6}{*}{ 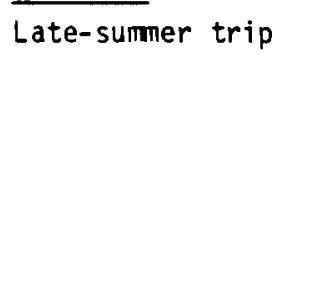 } & $\mathrm{CH}-5$ (Profile) & \\
\hline & $0-7.6 \mathrm{~cm}$ & 2.0 \\
\hline & $7.6-15.2 \mathrm{~cm}$ & \\
\hline & $\mathrm{CH}-7$ (Profile) & \\
\hline & $0-7.6 \mathrm{~cm}$ & 2.0 \\
\hline & $7.6-15.2 \mathrm{~cm}$ & 3.1 \\
\hline
\end{tabular}

(a) Concentrations are in $\mu g$ of uranium per $g$ of sample, with an estimated analytical error of $\pm 35 \%$.

(b) Rerun analysis.

(c) Collected upstream from main grid. 
TABLE B.2. (contd)

\begin{tabular}{|c|c|c|}
\hline Location & Sample/Grid Number & Uranium Concentration, $\mu g / g(a)$ \\
\hline \multicolumn{3}{|l|}{ Ford's Farm, Main Grid (Area 1) } \\
\hline \multirow[t]{15}{*}{ Early-spring trip } & Q-16 & 67 \\
\hline & $0-17$ & 30 \\
\hline & $0-18$ & 9.2 \\
\hline & Q-18 & 5.0 \\
\hline & M-19 & 8.5 \\
\hline & $L-20$ & 1.7 \\
\hline & $M-20$ & 6.5 \\
\hline & $0-20$ & 1.7 \\
\hline & $x-17(b)$ & 1.0 \\
\hline & $w-19^{(b)}$ & 1.1 \\
\hline & $k-20(b)$ & 3.0 \\
\hline & $T-25^{(b)}$ & 2.1 \\
\hline & $\mathrm{S}-25^{(\mathrm{b})}$ & 1.3 \\
\hline & $N-26^{(b)}$ & 1.2 \\
\hline & $E-26(b)$ & 0.76 \\
\hline \multicolumn{3}{|l|}{$\begin{array}{l}\text { Ford's Farm, 1000-Meter Pad } \\
\text { (Area 2) }\end{array}$} \\
\hline Early-spring trip & $M P-3$ & 0.56 \\
\hline \multicolumn{3}{|l|}{$\begin{array}{l}\text { Ford's Farm, Plate Storage } \\
\text { (Area 3) }\end{array}$} \\
\hline \multirow[t]{2}{*}{ Early-spring trip } & PS-1 & 0.64 \\
\hline & PS-2 & 2.1 \\
\hline \multicolumn{3}{|l|}{$\begin{array}{l}\text { Ford's Farm, Bridge Creek } \\
\text { (Area 4) }\end{array}$} \\
\hline \multirow[t]{7}{*}{ Late-summer trip } & GS-17 & $64(4.9)(c)$ \\
\hline & GS-19 & 5.0 \\
\hline & GS-16 (Profile) & \\
\hline & $0-2.5 \mathrm{~cm}$ & 1.5 \\
\hline & $2.5-5.1 \mathrm{~cm}$ & 1.9 \\
\hline & $5.1-7.6 \mathrm{~cm}$ & 1.3 \\
\hline & $7.6-15.2 \mathrm{~cm}$ & 0.93 \\
\hline \multicolumn{3}{|l|}{$\begin{array}{l}\text { Ford's Farm, Grenade Range } \\
\text { (Area 5) }\end{array}$} \\
\hline \multirow[t]{2}{*}{ Early-spring trip } & $G R-10$ & 0.83 \\
\hline & GR-11 & 2.1 \\
\hline
\end{tabular}

(a) Concentrations are in $\mu g$ of uranium per $g$ of sample, with an estimated analytical error of $\pm 35 \%$.

(b) collected from fringe areas of the main grid.

(c) Rerun analysis. 
TABLE B.3. Uranium Concentrations in All water Samples Collected $\frac{\text { Location }}{\text { B-3 Range, Main Grid (Area 1) }}$ Sample/Grid Number Uranium Concentration, $\mu g / L(a)$

\begin{tabular}{lll}
\hline Early-spring trip & $\mathrm{N}-9$ & 0.10 \\
$0-15$ & 1.7 \\
$\mathrm{M}-16$ & 3.7 \\
$\mathrm{M}-18$ & $9.6(18)^{(\mathrm{b})}$ \\
$\mathrm{M}-20$ & 1.7 \\
$\mathrm{~N}-23$ & 2.4 \\
$\mathrm{H}-5(\mathrm{c})$ & 12 \\
$\mathrm{~L}-7$ (c) & 0.81 \\
$\mathrm{E}-20(\mathrm{c})$ & $43 \quad(44)^{(\mathrm{b})}$ \\
$\mathrm{A}-22(\mathrm{c})$ & 4.4 \\
Late-summer trip & $\mathrm{N}-14$ & 0.71 \\
& $\mathrm{~N}-17$ & 0.80 \\
$\mathrm{M}-18$ & 0.42
\end{tabular}

B-3 Range, Beaver Dam (Area 2)

Late-summer trip

GS-1

$<D L^{(d)}$

GS-2

0.03

GS-4

0.06

GS-7

0.19

B-3 Range, Reference Area

TArea 3)

Late-sumer trip

$\begin{array}{ll}\text { GS }-60 & 0.14 \\ \text { GS-61 } & 0.20 \\ \text { CH-9 } & 0.12\end{array}$

Ford's Farm, Main Grid

Area 1)

Early-spring trip

$\begin{array}{ll}Q-16 & 35 \\ 0-18 & 12 \\ M-20 & 59 \\ W-9(e, f) & 43 \quad(33)^{(b)} \\ X-16(e) & 5.4 \\ K-20(e) & 40 \\ V-24(e) & 11 \\ N-26(e) & 16\end{array}$

(a) Concentrations are in $\mu g$ of uranium per $L$ of sample, with an estimated analytical error of $\pm 35 \%$.

(b) Rerun analysis.

(c) Collected upstream from the main grid.

(d) Less than detection level, indicating an estimated analytical error greater than $100 \%$.

(e) Collected from fringe areas of the main grid.

(f) Collected from an abandoned farm well in the area. 
TABLE B.3. (contd)

Location

Late-summer trip

Sample/Grid Number Uranium Concentration, $\mu \mathrm{g} / \mathrm{L}(\mathrm{a})$

$M-17$

16

Ford's Farm, 1000-Meter Pad

(Area 2)

Early-spring trip

$M P-4$

4.9

Ford's Farm, Plate Storage

(Area 3)

Early-spring trip

PS-3

5.0

Ford's Farm, Bridge Creek

(Area 4)

Late-summer trip

GS-14

1.6

GS-15

3.1

Ford's Farm, Grenade Range

(Area 5)

Early-spring trip

J -5

3.8

Late-summer trip

JA-5

0.13

Ford's Farm, Romney Creek

Area 6)

Late-sumner trip

PI-2

0.26

(a) Concentrations are in $\mu g$ of uranium per $L$ of sample, with an estimated analytical error of $\pm 35 \%$. 
TABLE B.4. Uranium Concentrations in All Vegetation Samples Collected

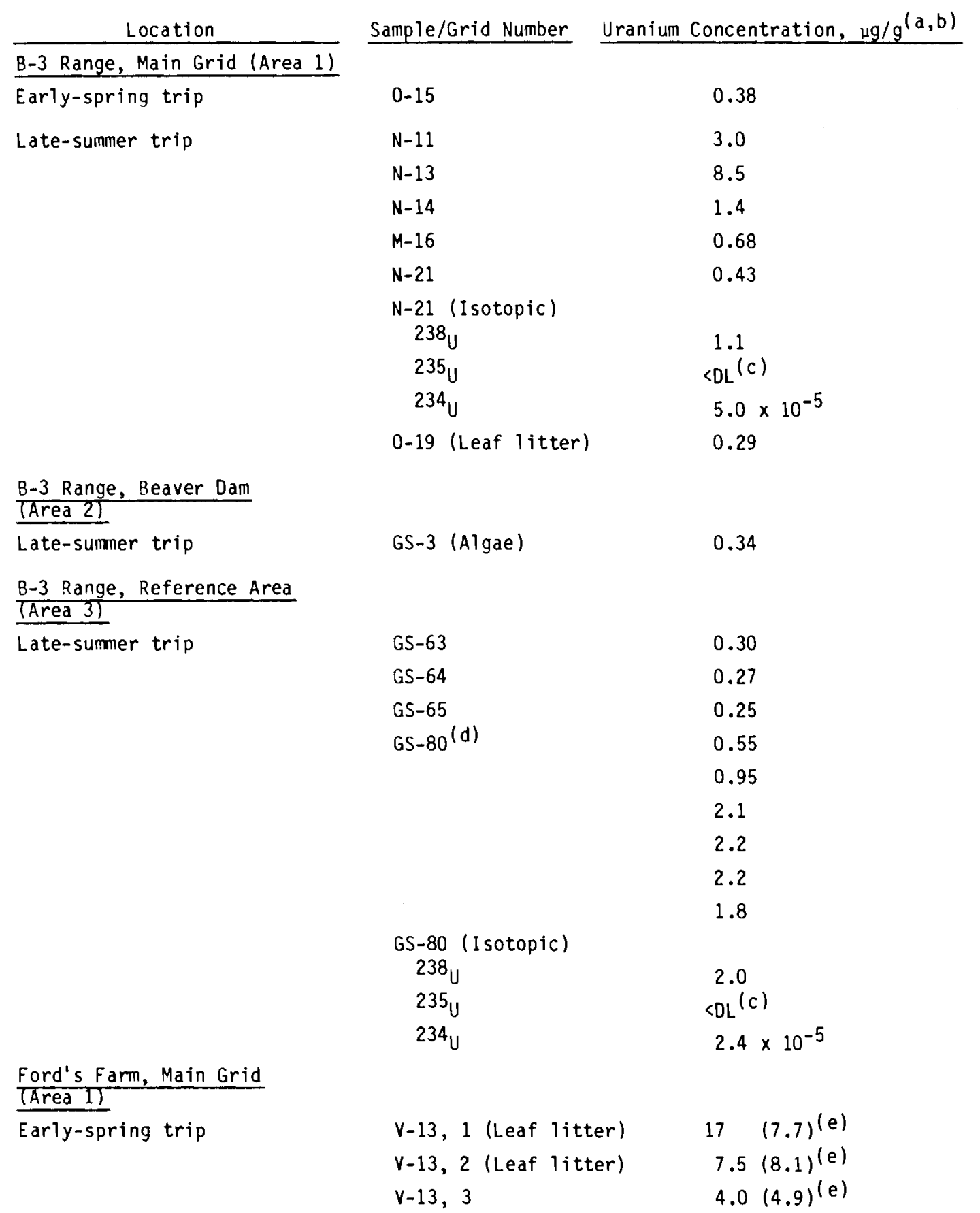

\footnotetext{
(a) Concentrations are in $u g$ of uranium per $g$ of sample, with an estimated analytical error of $\pm 35 \%$.

(b) Sample is grass unless otherwise noted.

(c) Less than detection level, indicating an estimated analytical error greater than $100 \%$.

(d) Six al iquots of sample were analyzed.

(e) Rerun analysis.
} 
TABLE B.4. (contd)

\begin{tabular}{|c|c|c|}
\hline Location & Sample/Grid Number & Uranium Concentration, $\mu \mathrm{g} / \mathrm{g}(\mathrm{a}, \mathrm{b})$ \\
\hline \multirow{33}{*}{ Late-summer trip } & $0-10$ & 2.6 \\
\hline & $0-11$ & 16 \\
\hline & $0-13$ & 13 \\
\hline & $0-15$ & 27 \\
\hline & $s-15$ & 14 \\
\hline & $M-16$ & 13 \\
\hline & $N-16$ & 75 \\
\hline & $0-16$ & 78 \\
\hline & $P-16(c)$ & 390 \\
\hline & & 1200 \\
\hline & & 720 \\
\hline & & 740 \\
\hline & & 590 \\
\hline & & 670 \\
\hline & P-16 (Isotopic) & \\
\hline & $238_{U}$ & 43 \\
\hline & $235_{U}$ & 0.11 \\
\hline & $234_{U}$ & $3.2 \times 10^{-4}$ \\
\hline & Q-16 & 16 \\
\hline & $R-16$ & 29 \\
\hline & S-16 & 2.9 \\
\hline & $T-16$ & 7.3 \\
\hline & $N-17$ & 25 \\
\hline & $P-17$ & 22 \\
\hline & $R-17$ & 26 \\
\hline & $0-18$ & 18 \\
\hline & $P-18$ & 10 \\
\hline & P-19 & 4.6 \\
\hline & $P-21$ & 1.5 \\
\hline & K-16 (Leaf 1itter) & 82 \\
\hline & $\begin{array}{l}\text { K-16 (Isotopic) } \\
238\end{array}$ & \\
\hline & $235_{U}$ & $<D L(d)$. \\
\hline & $234_{U}$ & $1.7 \times 10^{-5}$ \\
\hline
\end{tabular}

\footnotetext{
(a) Concentrations are in $\mu \mathrm{g}$ of uranium per $g$ of sample, with an estimated analytical error of $\pm 35 \%$.

(b) Sample is grass unless otherwise noted.

(c) Six aliquots of sample were analyzed.

(d) Less than detection level, indicating an estimated analytical error greater than $100 \%$.
} 
TABLE B.4. (contd)

Location

Sample/Grid Number Uranium Concentration, $\mu \mathrm{g} / \mathrm{g}(\mathrm{a}, \mathrm{b})$

T-16 (Leaf litter) 170

T-16 (Isotopic)

$238_{U} \quad 6.9$

$235 \mathrm{U}$

$1.8 \times 10^{-2}$

$234_{\mathrm{U}}$

$4.7 \times 10^{-5}$

L-16 (Leaf litter)

240

R-17 (Leaf litter)

10

Q-18 (Leaf 1itter)

150

Ford's Farm, 1000-Meter Pad

(Area 2)

Early-spring trip

$M P-5$

$4.8(8.3)^{(c)}$

MP -6

$4.3(4.3)^{(c)}$

Ford's Farm, Bridge Creek (Area 4)

Late-summer trip

GS-11

8.0

GS-11 (I sotopic)

$238_{U}$
$235_{U}$
$234_{U}$

GS-10 (Leaf litter)

1.7

GS-12 (Leaf litter)

$<D L(d)$

$2.5 \times 10^{-5}$

7.0

13

Ford's Farm, Grenade R.ange (Area 5)

Early-spring trip

GR-12 (Leaf litter)

5.8

GR-13

$2.5(1.7)^{(c)}$

Late-summer trip

GS -30

5.7

GS-30 (I sotopic)

$238_{\mathrm{U}}$

8.7

$235_{\mathrm{U}}$

$1.7 \times 10^{-2}$

$234 \mathrm{U}$

$5.5 \times 10^{-5}$

GS-31

7.1

GS -32

0.63

GS -33

$2.4(5.3)^{(c)}$

GS-35

0.19

(a) Concentrations are in ug of uranium per $g$ of sample, with an estimated analytical error of $\pm 35 \%$.

(b) Sample is grass unless otherwise noted.

(c) Rerun analysis.

(d) Less than detection level, indicating an estimated analytical error greater than $100 \%$. 
TABLE B.4. (contd)

Location

Sample/Grid Number Uranium Concentration, $\mu \mathrm{g} / \mathrm{g}(\mathrm{a}, \mathrm{b})$

JA-1 (Leaf litter) 2.9

JA-1 (Isotopic)

$238_{\mathrm{U}}$

$235_{U}$

$1.4 \times 10^{-2}$

$234 \mathrm{U}$

$3.5 \times 10^{-5}$

JA-2 (Leaf litter)

2.6

JA-3 (Leaf litter)

3.8

JA-4 (Leaf litter)

11

Ford's Farm, Romney Creek

Area 6)

Late-summer trip

PI-3 (Leaf Titter)
PI-3 (Isotopic)
$238_{U}$
$235 U$
$234_{U}$

0.93

1.8

$\angle D L(c)$

$1.5 \times 10^{-5}$

(a) Concentrations are in $\mu g$ of uranium per $g$ of sample, with an estimated analytical error of $\pm 35 \%$.

(b) Sample is grass uniess otherwise noted.

(c) Less than detection level, indicating an estimated analytical error greater than $100 \%$. 
APPENDIX C

SPECIAL-STUDIES DATA 
APPENDIX C

SPECIAL-STUDIES DATA

The data from two special studies are presented in this section: 1) a dissolution rate study and 2) a study of the concentrations of dissolved and suspended uranium concentrations in water samples.

DISSOLUTION RATF. STUDY

The purpose of this study was to determine what percent of depleted uranium dust would go into solution when exposed over a 14-day period to sea water and river water with controlled water temperature and a known $\mathrm{pH}$.

Method

A weighed amount of DU dust was placed in each of four vials, then $50 \mathrm{ml}$ of sea water were added to one pair of vials and $50 \mathrm{ml}$ of river water to the other pair. The sea water came from Sequim, Washington, on the Pacific Coast, and had heen filtered through a $0.45-u m$ filter. The river water came from the Columbia River and had been filtered through a 100-um filter. A water bath shaker was used for shaking the contents of the vials and controlling the water temperature at $10^{\circ} \mathrm{C}$. One-ml samples of the uranium and water were drawn from each vial on days $1,2,4,8$, and 14 . Each sample was filtered through a $0.1-\mu m$ filter, and fluorometric and colorimetric analyses were done. The error assigned to each sample was $30 \%$ for the fluorometric analysis and $10 \%$ for the colorimetric analysis. The $\mathrm{pH}$ of the solution in each vial was measured on the first and last day.

Results

The results of the dissolution of the Du dust in $10^{\circ} \mathrm{C}$ Pacific sea water and Cnlumbia River water are listed in Table C.1 and graphed in Figures C.1 and C.2. 
TABLE C.1. Sample Data from the Dissolution Rate Study

\begin{tabular}{|c|c|c|c|c|c|c|c|c|c|c|c|c|}
\hline Sample & DU Dust, mg & Water, $m l$ & $\begin{array}{c}\text { Concentration, } \\
\mathrm{mg} / \mathrm{ml}]\end{array}$ & Day 1 & DH & Day $1^{-}$ & $\begin{array}{l}\text { ncentration } \\
\text { Day ? }\end{array}$ & $\begin{array}{l}\text { from Fluoro } \\
\text { Day } 4 \\
\end{array}$ & $\begin{array}{l}\text { etric Ana } \\
\text { Day } 8 \\
\end{array}$ & $\begin{array}{l}\text { ys is } \\
\text { Day } 14\end{array}$ & $\begin{array}{l}\text { Dissolution } \\
\text { Rate } \\
\text { (\% of Total } \\
\text { Sample/Day) }\end{array}$ & $\begin{array}{c}\text { Estimated } \\
\text { First } \\
\text { Dissolution } \\
\text { Half-Time, yr }\end{array}$ \\
\hline $\begin{array}{l}\stackrel{\# 1}{\text { DU }+ \text { Sea }} \\
\text { Water }\end{array}$ & 545.1 & 50 & 10.9 & 7.99 & 7.05 & $57 \pm 17$ & $17 \pm 5$ & $10 \pm 3$ & $33 \pm 10$ & $\begin{array}{r}3 \pm 1 \\
62 \pm 4(a)\end{array}$ & 0029 & 48 \\
\hline $\begin{array}{l}\quad \# 2 \\
\text { OU }+ \text { Sea } \\
\text { Water }\end{array}$ & 545.6 & 50 & 10.91 & 8.0 & 6.5 & $57 \pm 17$ & $\begin{aligned} 2 & \pm 1 \\
17 & \pm 5 \\
25 & \pm 2(a)\end{aligned}$ & $39 \pm 12$ & $28 \pm 8$ & $19 \pm 6$ & $0.0<0$ & 4.0 \\
\hline $\begin{array}{l}\text { \#3 } \\
\text { OU + River } \\
\text { Water }\end{array}$ & 674.2 & 50 & 13.48 & 8.8 & 8.25 & $36 \pm 4$ & $\begin{aligned} 7 & \pm 2 \\
25 & \pm 2(a)\end{aligned}$ & $34 \pm 10$ & $51 \pm 15$ & $\begin{array}{l}12 \pm 4 \\
78 \pm 6(a)\end{array}$ & & \\
\hline $\begin{array}{l}\stackrel{\# 4}{ } \\
\text { DU }+ \text { River } \\
\text { Water }\end{array}$ & 642.3 & 50 & 12.85 & 8.7 & 8.0 & $32 \pm 3$ & $40 \pm 12$ & $27 \pm 2^{(a)}$ & $45 \pm 13$ & $52 \pm 15$ & 0.020 & 6.8 \\
\hline $\begin{array}{l}\text { \#5 } \\
\text { Uranyl } \\
\text { Nitrate + } \\
\text { Sea Water } \\
\text { (Standard) }\end{array}$ & $\begin{array}{l}3.8 \cup \text { nitrate } \\
1.801 \mathrm{U}^{-}\end{array}$ & 100 & 0.018 & 7.7 & 7.5 & $25 \pm 3$ & $\begin{array}{l}25 \pm 8(a) \\
20 \pm 1\end{array}$ & $19 \pm 6$ & $21 \pm 6$ & $14 \pm 4$ & & \\
\hline $\begin{array}{l}\text { \#6 } \\
\text { River Water }\end{array}$ & 0 & 50 & 0 & 8.1 & 7.2 & 0.0004 & & & & & & \\
\hline $\begin{array}{c}\# 7 \\
\text { Sea Water }\end{array}$ & 0 & 50 & 0 & & & 0.0003 & & & & & & \\
\hline
\end{tabular}




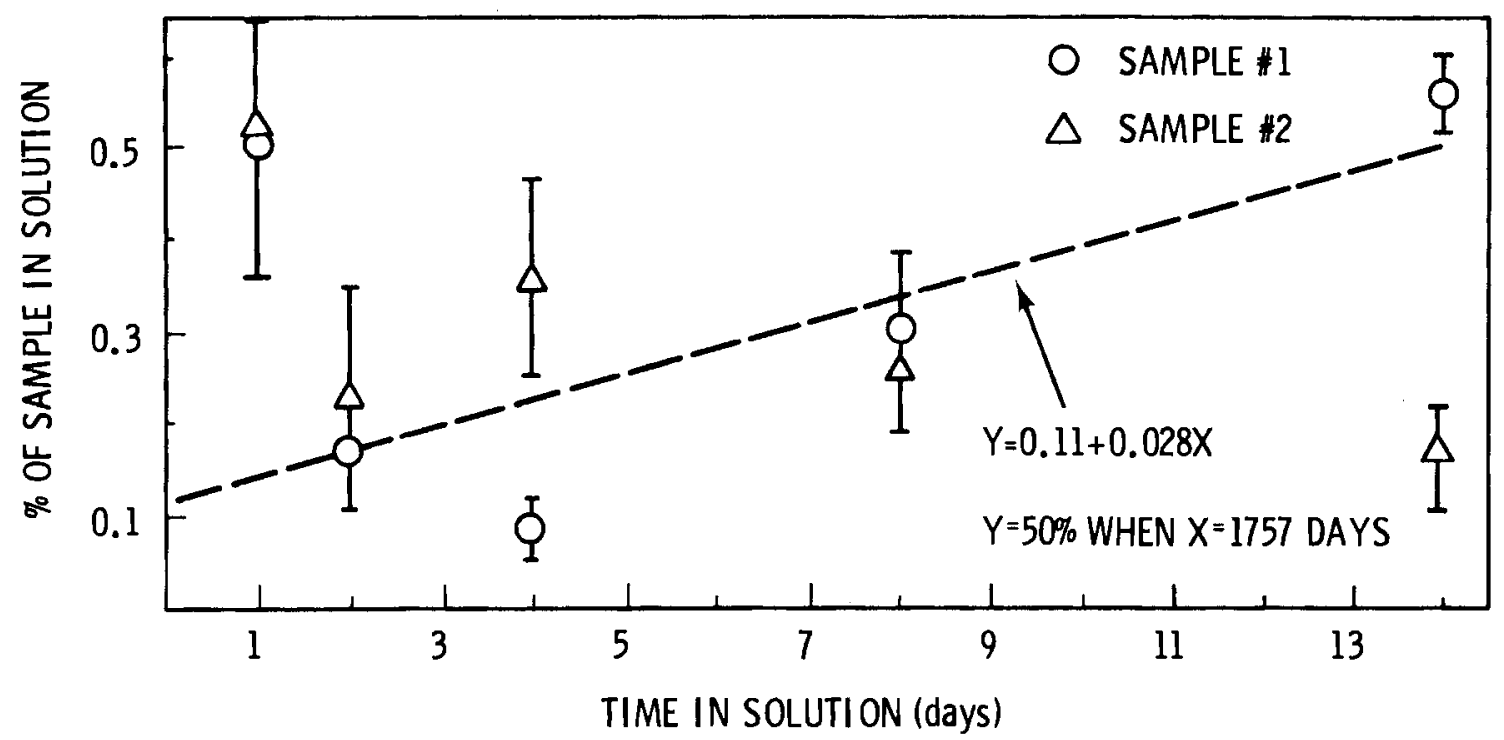

FISIJRE C.1. Dissolution of Uranium Dust in Sea Water at $10^{\circ} \mathrm{C}$

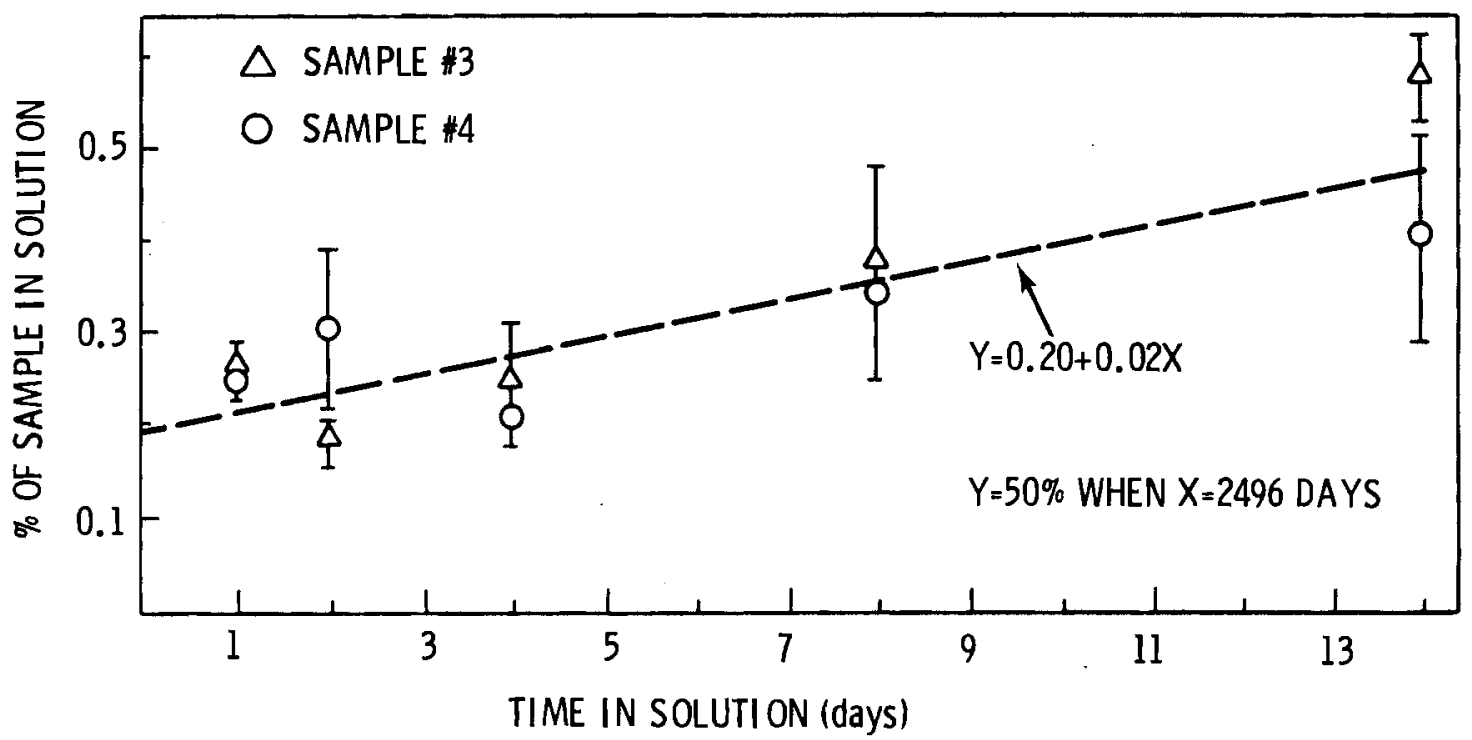

FIGIJRE C.2. Dissolution of Uranium Dust in River water at $10^{\circ} \mathrm{C}$

Sea water at $10^{\circ} \mathrm{C}$. During the 14 days of the experiment, the $\mathrm{pH}$ of the sea water dropped more than 0.9 units. The percent of each sample that has gone into solution during this time is shown in Figure C.1. as a function of time. The percent was calculated assuming that the total mass of sample dust placed into the vial consists of DU metal only. Correcting for the presence of oxides and dust particles from other sources must wait until the test sample is analyzed for total uranium content. 
The dissolution measurements made on day 1 for samples \#1 and \#2 and on day 14 for sample \#2 were not included in the linear regression of the data. The sea water measurements were restricted to the $\mathrm{pH}$ range 7.5 to 7.0. The DU appears to be relatively insoluble in sea water, having a half-time for dissolution of 4.8 years.

River Water at $10^{\circ} \mathrm{C}$. During the 14 days of the experiment, the $\mathrm{pH}$ of the river water dropped approximately 0.6 units in both of the sample vials. This appears not to have appreciably affected the dissolution of the uranium in the water; the dissolution rate steadily increases, as can be seen in Figure C.2. The DU appeared to be relatively insoluble, having a half-time of dissolution of 6.8 years. The actual dissolution may be faster because wall losses were not included in this calculation. Wall losses were estimated using a standard solution of uranyl nitrate $(18 \mu \mathrm{g} / \mathrm{ml})$ in which the amount of dissolved uranium decreased to $60 \%$ of the original concentration by the fourteenth day (see Figure C.3).

\section{Comments}

In future work, the $\mathrm{pH}$ must be kept constant to eliminate any effects of $\mathrm{pH}$ on the rate of uranium dissolution. This should be done through the use of buffers and through repeated measurement of the $\mathrm{pH}$ of each solvent sample.

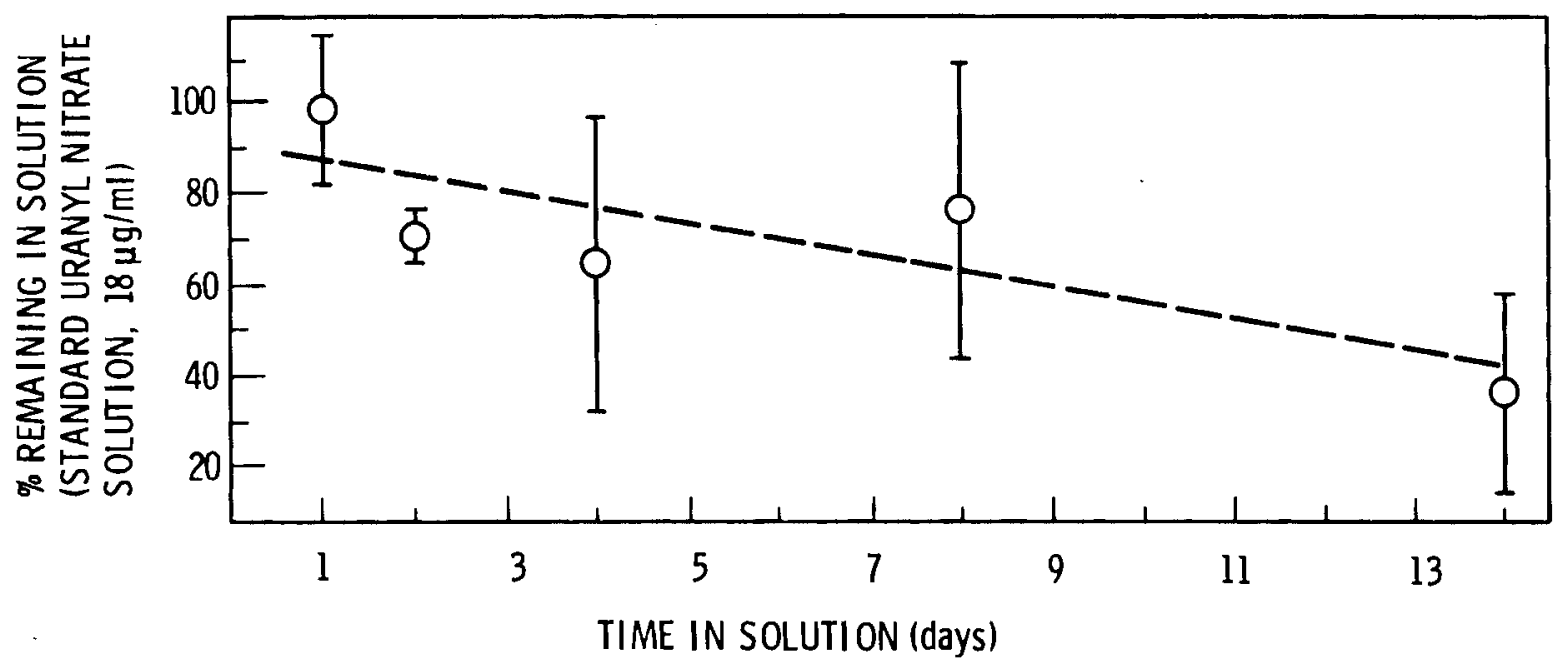

FIGURF. C.3. Changes in Uranium Concentration in a Standard Uranyl Nitrate Solution Due to Wall Losses 
The fraction of material dissolved should be normalized to the surface area of the sample, giving units of percent in solution per $\mathrm{cm}^{2}$ of sample. This correction can be obtained by dividing the concentrations given in Table $C .1$ by the specific surface of the sample, $S p\left(\mathrm{~cm}^{2} / \mathrm{gm}\right)$, and by multiplying each point in Figures $C_{.1}$ and $C .2$ by Mo/Sp, where Mo is the initial sample weight.

ANALYSES DF DISSOLVED VERSUS SUSPENDED URANIUM

Table C.2 is a list of the data from the two water samples analyzed for dissolved uranium $(<0.45-\mu m$ particles) and suspended uranium $(>0.45-\mu m$ particles).

Table C.2. Dissolved and Suspended Uranium Concentrations in Water Samples from the Ford's Farm Range

\begin{tabular}{|c|c|c|c|c|}
\hline Sample & $\begin{array}{c}\text { Uranium } \\
\text { Dissolved } \\
\text { in Water, } \\
\mu \mathrm{g} / \mathrm{L} \\
\end{array}$ & $\begin{array}{c}\text { Uranium in } \\
\text { Suspended } \\
\text { Sediments, } \\
\mu \mathrm{g} / \mathrm{L} \\
\end{array}$ & $\begin{array}{c}\text { Total } \\
\text { Uranium, } \\
\mu \mathrm{g} / \mathrm{L} \\
\end{array}$ & $\begin{array}{l}\text { IJranium } \\
\text { Solution (\%) } \\
\end{array}$ \\
\hline$M-17 W$ (main grid) & 19 & 3.8 & 23 & 83 \\
\hline $\begin{array}{l}\text { CSS-15H (Rritge } \\
\text { Creek area) }\end{array}$ & 4.2 & 3.9 & 8.1 & 52 \\
\hline
\end{tabular}




\section{DISTRIBUTION}

No. of

Copies

OFFSITE

Office of Secretary of Defense Office of Director of Defense, Research and Engineering

ATTN: Mr. J. Persh

Washington, DC 20301

Office of Assistant Secretary of Defense for Atomic Energy ATTN: CMDR G. Cliff

Pentagon, Room 3E1069

Washington, DC 20310

Office of the Undersecretary of the Army

Deputy Undersecretary

(Operations Research)

ATTN: Mr. D. Hardison

Department of the Army

Washington, DC 20310

Undersecretary of Defense for Research and Engineering

Deputy Undersecretary

(Tactical Warfare Programs)

Department of Defense

Washington, DC 20310

Undersecretary of Defense for Research and Engineering

Deputy Undersecretary

(Tactical Warfare Programs)

ATTN: Mr. C. Mckinley

Department of Defense

Washington, DC 20310

Undersecretary of Defense for

Research and Engineering

Deputy Undersecretary

(Tactical Warfare Programs)

ATTN: Mr. R. Moore

Department of Defense

Washington, DC 20310
No. of

Copies

Undersecretary of Defense for Research and Engineering

Deputy Undersecretary (Research and Advanced Technology)

ATTN: Dr. Ruth Davis

Department of Defense

Washington, DC 20310

Office of the Deputy Undersecretary of Defense, Research and Engineering

ATTN: $M r$. R. Thorkildsen

Pentagon

Washington, DC 20310

Headquarters

Department of the Army

ATTN: DASG-TSP-E, COL Wangemann Washington, DC 20310

Headquarters

Department of the Army

ATTN: DACS-DMT

Washington, DC 20310

Headquarters

Department of the Army

ATTN: DAMA-ARX-A, Dr. M. Lasser Washington, DC 20310

Headquarters

Department of the Army

ATTN: DAMA-CSS, Dr. J. Bryant

Washington, DC 20310

Headquarters

Department of the Army

ATTN: DAMA-CSM, LTC German

Washington, DC 20310

Headquarters

Department of the Army

ATTN: DAMA-CSM-CA, Mr. Lippi

Washington, DC 20310 
No. of

Copies

Headquarters

Department of the Army

ATTN: DAMA-WSW, LTC Hinson

Washington, DC 20310

Headquarters

Department of the Army

ATTN: DAMO-TRS

Washington, DC 20310

Headquarters

Department of the Army

ATTN: DAMO-TRI

Washington, DC 20310

Headquarters

Department of the Army

ATTN: DALO-SMS, Ms. T. Ueckert

Washington, DC 20310

Headquarters

Department of the Army

ATTN: SAIL-SN, Mr. Hildebrand

Washington, DC 20310

Commander

U.S. Army Combined Arms Combat Development Activity

ATTN: APCA-BC

Fort Leavenworth, KS 66027

2 Commander

U.S. Army Environmental Hygiene Agency

ATTN: HSE-0, COL. J. Thiessen

Aberdeen Proving Ground, MD 21005

5 Commander

U.S. Army Armament Research and Development Command

ATTN: DRDAR-SCM-P, Dr. E. Bloore Dover, NJ 07801

\section{Director}

U.S. Army Human Engineering Laboratory

ATTN: DRXHE-HE, Mr. Erickson

Aberdeen Proving Ground, MD 21005
No. of

Copies

\section{Project Manager}

XMI Tank System

ATTN: DRCPM-GCM, MG Babers

Warren, MI 48090

2 Project Manager

XMI Tank System

ATTN: DRCPM-GCM-SI, Mr. D. Bartle

Warren, MI 48090

Project Manager

M60 Tank

Michigan Army Missile Plant

ATTN: DRCPM-M60

Warren, MI 48090

Commander

U.S. Army Tank Automotive Research and Development Command

ATTN: DRDTA-RWL

Warren, MI 48090

Commander

U.S. Army Tank Automotive Research and Development Command

ATTN: DRDTA-RKA, Mr. V. Pagano

Warren, MI 48090

Project Manager

Tank Main Armament System

ATTN: DRCPM-TMA-102mm, Mr. Krosser

Dover, NJ 07801

5 Project Manager

Tank Main Armament System

ATTN: DRCPM-TMA, Mr. Mahler (1) DRCPM-ARM-105, LTC Scarboro (2) DRCPM-APM-230, LTC Howard (2)

Dover, NJ 07801

Project Manager

Production Base Modernization and Exp

ATTM: DRCPM-PBM, Mr. C. Kolis Dover, NJ 07801 
No. of

Copies

Commander

U.S. Army Logistics Center

ATTN: ATCL-M, Mr. Thompson

Fort Lee, VA 23801

Commander

U.S. Amy Missile Munitions

ATTN: ATSK-CD

Redstune Arsenal, AL 35809

Commander

U.S. Army Logistics Evaluation Agency

ATTN: DALO-LEI, Mr. Frye

New Cumberland Army Depot

New Cumberland, PA 17070

Commander

U.S. Army Materiel Development and Readiness Command

ATTN: DRCDR-DW, COL Collins

5001 Eisenhower Avenue

Alexandria, VA 22333

Commander

U.S. Army Materiel Development and Readiness Command

ATTN: DRCQA, Mr. R. Fahy

5001 Eisenhower Avenue

Alexandria, VA 22333

Commander

U.S. Army Materiel Development and Readiness Command

ATTN: DRCDMD, LTG Gonzals

5001 Eisenhower Avenue

Alexandria, VA 22333

Commander

U.S. Army Materiel Development and Readiness Command

ATTN: DRCDMA-ST

5001 Eisenhower Avenue

Alexandria, VA 22333
No. of

Copies

Commander

U.S. Army Materiel Development and Readiness Command

ATTN: DRCSMA-ST, COL Vincent

5001 Eisenhower Avenue

Alexandria, VA 22333

Commander

U.S. Army Materiel Development and Readiness Command

ATTN: DRCSG, COL R. Cutting

5001 Eisenhower Avenue

Alexandria, VA 22333

Commander

U.S. Army Materiel Development and Readiness Command

ATTN: DRCPA-E, Mr. Pace

5001 Eisenhower Avenue

Alexandria, VA 22333

3 Commander

U.S. Army Materiel Development and Readiness Command

ATTN: DRCSF-P, Mr. Taras

5001 Eisenhower Avenue

Alexandria, VA 22333

Director

DARCOM Field Safety Activity

ATTN: DRXOS-ES, Mr. E. 01 sen

Charlestown, IN 47111

Director

U.S. Army Materials and Mechanics Research Center

ATTN: DRXMR-X, Dr. E. Wright Watertown, MA 02172

Director

U.S. Army Materials and Mechanics Research Center ATTN: DRXMR-AR, Mr. S. Levin Watertown, MA 02172

Director

U.S. Army Materiels Systems Analysis Agency

ATTN: DRXSY

Aberdeen Proving Ground, MD 21005 
No. of

Copies

Director

U.S. Army Materiels Systems Analys is Agency

ATTN: DRXSY-GA, Mr. W. Brooks

Aberdeen Proving Ground, MD 21005

Commander

U.S. Army Armament Materiel Readiness Command

ATTN: DRSAR-MAD-C, Mr. P. Shaw Dover NJ 07801

Commander

U.S. Army Armament Materiel Readiness Command

ATTN: DRSAR-ASR

Rock Island, IL 61201

Commander

U.S. Army Armament Materiel Readiness Command

ATTN: DRSAR-LEA, Mr. E. Beckman

Rock I sland, IL 61201

3 Commander

U.S. Army Armament Materie1 Readiness Command

ATTN: DRSAR-SS, Mr. B. Morris

Rock I sland, IL 61201

Commander

U.S. Army Armament Research and Development Command

ATTN: DRDAR-CG

Dover, NJ 07801

Commander

U.S. Army Armament Research and Development Command

ATTN: DRDAR-TD

Dover, NJ 07801

Commander

U.S. Army Armament Research and Development Command

ATTN: DRDAR-SC

Dover, NJ 07801
No. of

Copies

Commander

U.S. Army Armament Research and Development Command

ATTN: DRDAR-LC, Dr. J. Frasier Dover, NJ 07801

Commander

U.S. Army Armament Research and Development Command

ATTN: DRDAR-SCM, J. Corrie Dover, NJ 07801

10 Commander

U.S. Army Armament Research and Development Command

ATTN: DRDAR-LCU-CT, Mr. Davitt Dover, NJ 07801

2 Commander

U.S. Army Armament Research and Development Command

ATTN: DRDAR-SF, Mr. Elliott

Dover, NJ 07801

5 Commander

U.S. Army Armament Research and Development Command

ATTN: DRDAR-TSS, STINFO

Dover, NJ 07801

Commander

U.S. Army Armament Research and Development Command

ATTN: DRDAR-BLT, Mr. R. Vitali

Aberdeen Proving Ground, MD 21005

Commander

U.S. Army Armament Research and Development Command

ATTN: DRDAR-BLT, Dr. W. Gillich Aberdeen Proving Ground, MD 21005

3 Commander

U.S. Army Armament Research and Development Command ATTN: DRDAR-BLV, Mr. E. Wilsey Aberdeen Proving Ground, MD 21005 
No. of

Copies

Commander

U.S. Army Armament Research and Development Command

ATTN: DRDAR-BLP, Mr. R. Comer

Aberdeen Proving Ground, MD 21005

Commander

U.S. Army Armament Research and Development Command

ATTN: DRDAR-AD-SA, Mr. Mark 1 and

Aberdeen Proving Ground, MD 21005

Commander

U.S. Army Armament Research and Development Command

ATTN: DRDAR-LCB, Mr. P. Rummel

Watervliet, NY 12189

Director

U.S. Army Ammunition Center

ATTN: SARAC-D, Mr. K. Croscost

Savanna, IL 61074

Commander

U.S. Army Armor Center and School

ATTN: Mr. M. Falkovitch

Fort Knox, KY 40121

Commander

U.S. Army Armor Center and School

ATTN: ATZK-CG-AM-L, LTC Robinson

Fort Knox, KY 40121

Commander

U.S. Army Missile Command

ATTN: DRCPM-LCE, Mr. Crosswhite

Redstone Arsenal, AL 35809

Commander

U.S. Army Mobility Equipment Research and Development Command

ATTN: DRSME-RZT, Tech DOC Ctr B/315

Fort Belvoir, VA 22060

Commander

U.S. Army Test and Evaluation Command

ATTN: DRSTE

Aberdeen Proving Ground, MD 21005
No. of

Copies

2 Commander

U.S. Army Test and Evaluation Command

ATTN: DRSTE-AR, Mr. Saubier DRSTE-AR, Mr. D. Witt

Aberdeen Proving Ground, MD 21005

2 Commander

U.S. Army Test and Evaluation Command

ATTN: DRSTE-CE

Aberdeen Proving Ground, MD 21005

2 Commander

U.S. Amy Test and Evaluation Command

ATTN: DRSTE-PP-E

Aberdeen Proving Ground, MD 21005

2 Commander

U.S. Army Test and Evaluation Command

ATTN: DRSTE-ST, Mr. J. Starkey

Aberdeen Proving Ground, MD 21005

Commander

U.S. Army Training and Doctrine Command

Fort Monroe,

Hampton, VA 23651

Commander

U.S. Army Training and Doctrine Command

ATTN: ATEM-SE, Mr. Dery

Fort Monroe,

Hampton, VA 23651

Commander

U.S. Army Training and Doctrine Command

ATTN: ATTR-HR-S, Mr. Teichmann

Fort Monroe,

Hampton, VA 23651

3 Commander

Aberdeen Proving Ground

ATTN: STEAP-MTD, Mr. H. Graves

Aberdeen Proving Ground, MD 21005 
No. of

Copies

Director

U.S. Army TRADOC Systems

Analys is ACt

ATTN: ATAA-SA

White Sands Missile Range, NM 88002

5 Commander

Defense Technical Information Center

ATTN: DDC-DDA

Cameron Station

Alexandria, VA 22314

Commander

U.S. Naval Sea Systems Command

ATTN: PMS-404-31, Mr. E. Gerlach

Washington, DC 20362

Commander

U.S. Naval Surface Weapons Center

ATTN: Code WR-32

White Oak, MD 20910

Commander

U.S. Naval Surface Weapons Center

ATTN: Code DG-52, W. Wishard

White Oak, MD 20910

$2 \mathrm{HQ}, \mathrm{ADTC} / \mathrm{DLV}$

ATTN: Dr. J. Cornette

Egl in AFB, FL 32542

HQ, ADTC

ATTI: CEEDO/CC Detachment 1

Tynda11 AFB, FL 32403

Air Force Materiel Laboratory

ATTN: YXD, CPT D. Schuur

Wright-Patterson AFB, OH 45433

U.S. Nuclear Regulatory Commission

Division of Fuel Cycle and

Material Safety

ATTN: Mr. E. Wright

Washington, DC 20555

National Lead Company of Ohio

ATTN: Mr. L. Levy

Box 39158

Cincinnati, $\mathrm{OH} \quad 45239$
No. of

Copies

Office of Nuclear Waste Isolation

ATTN: Mr. D. A. Waite

Columbus, $\mathrm{OH} 43201$

Rockwe11 International

Rocky Flats Plant

ATTN: Dr. M. Werkema

B1dg 123, P.0. Box 464

Golden, CO 80401

Union Carbide Corporation

Nuclear Division

ATTN: Mr. M. Sanders

P.O. Box Y

Oak Ridge, TN 37830

University of California

Los Alamos Scientific Laboratory

ATTN: Dr. D. Sandstrom, CMB-6

Los Alamos, NM 87544

27 DOE Technical Information Center

ONSITE

DOE Richland Operations Office

H. E. Ransom

41 Pacific Northwest Laboratory

J. L. Baer

L. G. Faust

R. L. Gilchrist (20)

J. A. Glissmeyer

D. E. Hadlock

C. D. Hooker

J. Mishima

L. H. Munson

B. L. Murphy

J. M. Selby

G. A. Stoetzel (5)

Publishing Coordination (2)

Technical Information (5) 